Nevada

Environmental

Restoration

Project

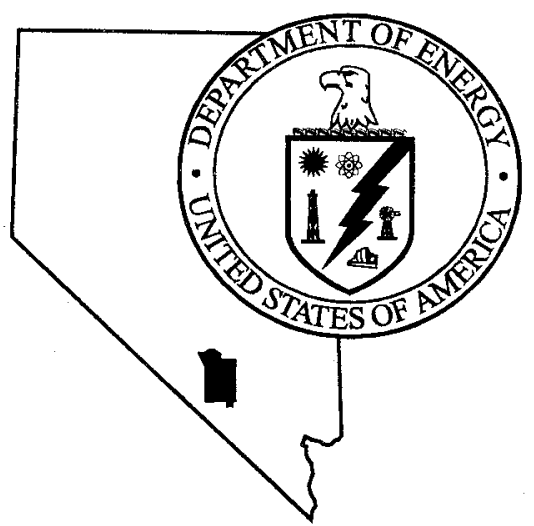

\title{
Closure Plan \\ for Corrective Action Unit 109: \\ U-2bu Subsidence Crater \\ Nevada Test Site, Nevada
}

Controlled Copy Number:

Revision: 0

March 1999

Distribution A - Approved for public release: further dissemination unlimited

Environmental Restoration

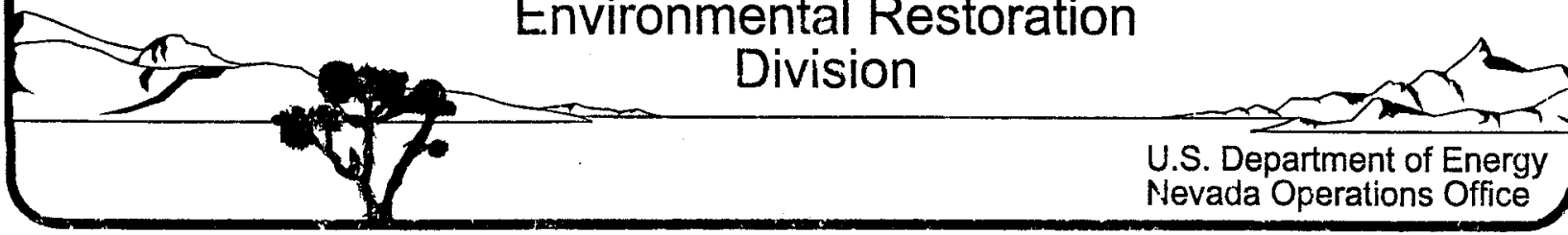


Available to the public from:

U. S. Department of Commerce

National Technical Information Service

5285 Port Royal Road

Springfield, VA 22161

(703) $487-4650$

Available electronically at http:/www.doe.gov/bridge. Available to the U.S. Department of Energy and its contractors in paper from:

U.S. Department of Energy

Office of Scientific and Technical Information

P.O. Box 62

Oak Ridge, TN 37831-0062

(423) 576-8401.

Reference herein to any specific commercial product, process, or service by trade name, trademark, manufacturer, or otherwise, does not necessarily constitute or imply its endorsement, recommendation, or favoring by the U.S. Government or any agency thereof or its contractors or subcontractors. 


\section{ERRATA SHEET}

The fourth sentence in the third paragraph on page A-2 of the Closure Plan for Corrective Action Unit 109: U-2bu Subsidence Crater. Nevada Test Site. Nevada erroneously states that drinking water well UE-16d is located southeast of the U-2bu subsidence crater. The sentence should state that the water well is located southwest of the U-2bu subsidence crater. 


\title{
CLOSURE PLAN FOR CORRECTIVE ACTION UNIT 109: U-2BU SUBSIDENCE CRATER, NEVADA TEST SITE, NEVADA
}

\author{
Controlled Copy No.:
}

Revision 0

March 1999

Prepared for the U.S. Department of Energy

Nevada Operations Office under Contract No. DE-AC08-96NV11718 
THIS PAGE INTENTIONALLY LEFT BLANK 


\section{CLOSURE PLAN FOR CORRECTIVE ACTION UNIT 109: U-2BU SUBSIDENCE CRATER, NEVADA TEST SITE, NEVADA}

Approved By: $\frac{\text { the }=- \text { Cablele to }}{\begin{array}{c}\text { Janet L. Appenzeller-Wing, Project Manager } \\ \text { Industrial Sites Project }\end{array}}$

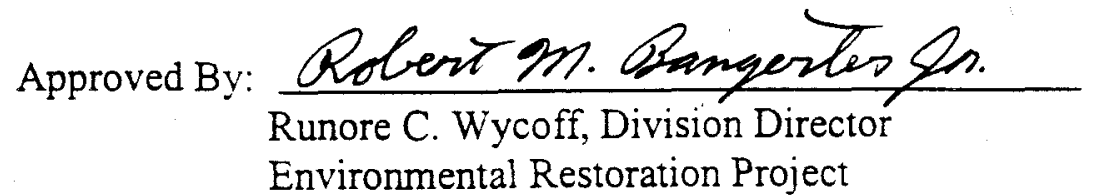

Date: $3 / 12 / 99$

Date: $3 / 12 / 45$ 
THIS PAGE INTENTIONALLY LEFT BLANK 


\section{TABLE OF CONTENTS}

FIGURES $\ldots \ldots \ldots \ldots \ldots \ldots \ldots \ldots \ldots \ldots \ldots \ldots \ldots \ldots \ldots \ldots \ldots$ vii

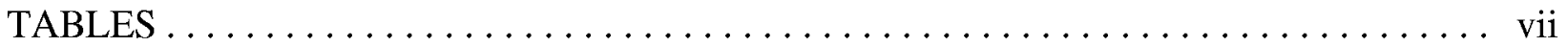

ACRONYMS AND ABBREVIATIONS $\ldots \ldots \ldots \ldots \ldots \ldots \ldots \ldots \ldots \ldots \ldots \ldots$ ix

EXECUTIVE SUMMARY $\ldots \ldots \ldots \ldots \ldots \ldots \ldots \ldots \ldots \ldots \ldots \ldots \ldots \ldots \ldots \ldots$

1.0 INTRODUCTION $\ldots \ldots \ldots \ldots \ldots \ldots \ldots \ldots \ldots \ldots \ldots \ldots \ldots \ldots \ldots \ldots \ldots \ldots$

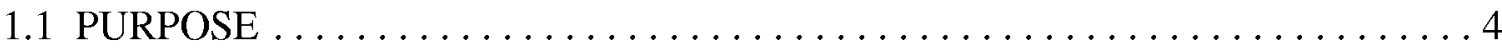

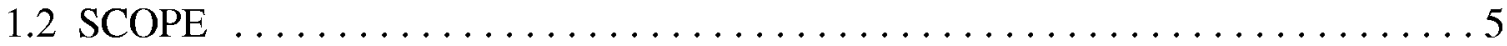

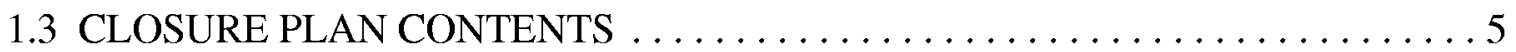

2.0 DETAILED STATEMENT OF WORK $\ldots \ldots \ldots \ldots \ldots \ldots \ldots \ldots \ldots \ldots \ldots \ldots$

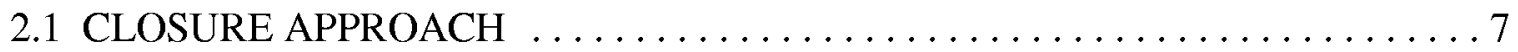

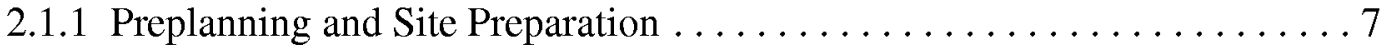

2.1.1.1 Site-Specific Health and Safety Plan/Job Hazard Analysis . . . . 7

2.1.1.2 Field Management Plan . . . . . . . . . . . . . 7

2.1.1.3 National Environmental Policy Act Documentation . . . . . . . 8

2.1.1.4 Pre-Excavation Activity Geoprobe ${ }^{\circledR}$ Sampling . . . . . . . . 8

2.1.1.5 Site Preparation . . . . . . . . . . . . . . . . 10

2.1 .2 Field Activities . . . . . . . . . . . . . . . . . . . . 10

2.1.2.1 Excavation of the Lead-Impacted Soil . . . . . . . . . 10

2.1.2.2 Decontamination of Equipment $\ldots \ldots \ldots \ldots \ldots \ldots \ldots \ldots$

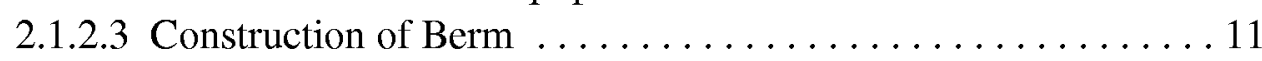

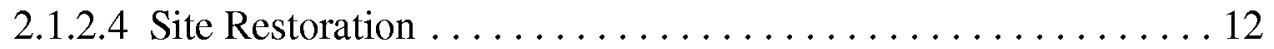

2.2 CONSTRUCTION QUALITY ASSURANCE/QUALITY CONTROL $\ldots \ldots \ldots 12$

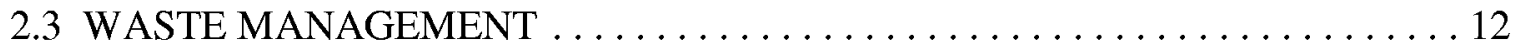

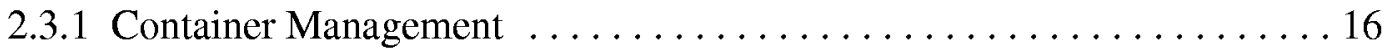

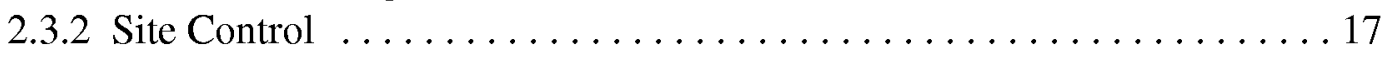

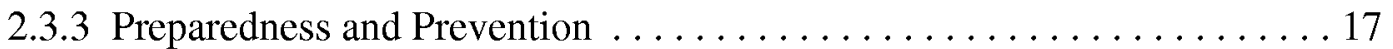

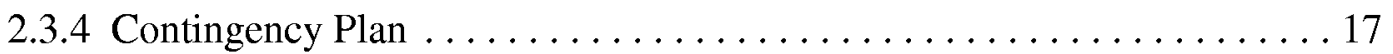

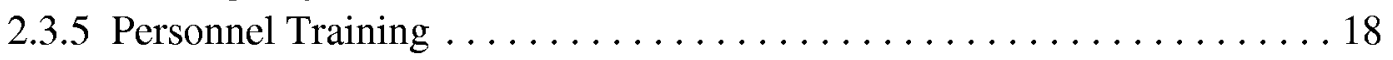

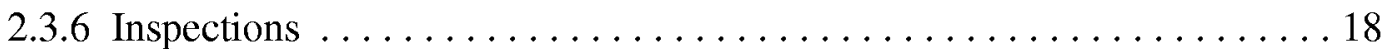

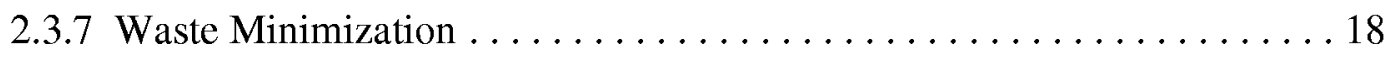

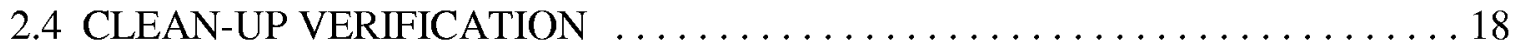

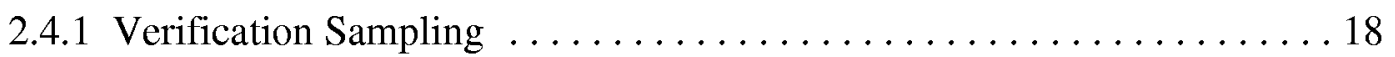

2.4 .2 Quality Control Samples .......................... 19 


\section{TABLE OF CONTENTS (Continued)}

2.5 PERMITS . . . . . . . . . . . . . . . . . . . . . . . . 21

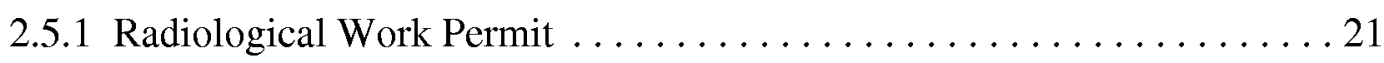

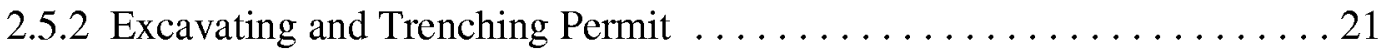

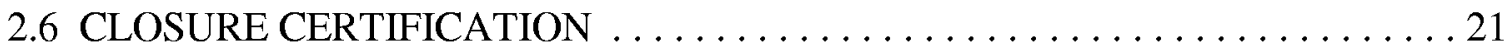

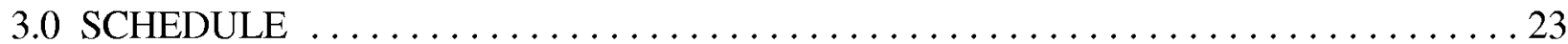

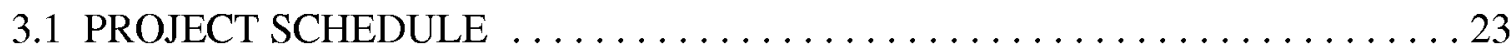

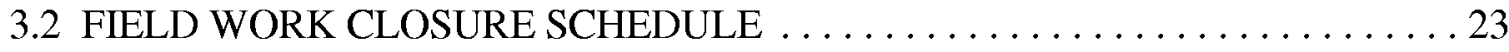

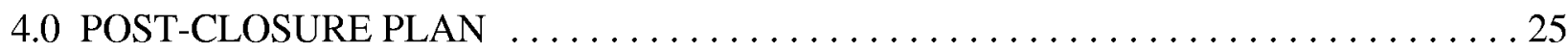

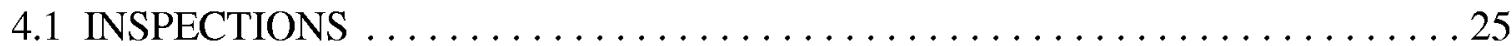

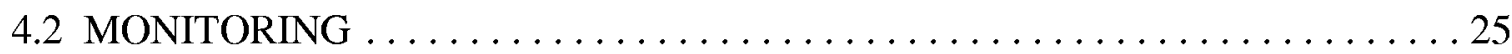

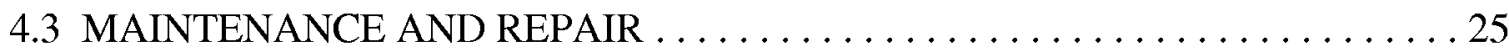

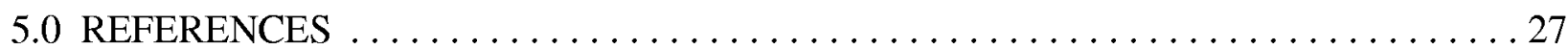

\section{APPENDICES}

Appendix A: "A Through K" Evaluation

Appendix B: Contingency Plan

Appendix C: Photographs of the U-2bu Subsidence Crater

Appendix D: Project Organization

Distribution List 


\section{TABLE OF CONTENTS (Continued)}

\section{FIGURES}

Figure 1 - Location of the U-2bu Subsidence Crater, Area 2, Nevada Test Site ........... 2

Figure 2 - Location of Site Characterization Samples at the U-2bu Subsidence Crater ....... 3

Figure 3 - Proposed Site Layout Plan for the U-2bu Subsidence Crater Field Work ........ 9

\section{TABLES}

Table 1 - Management of Various Waste Types to Be Produced at the

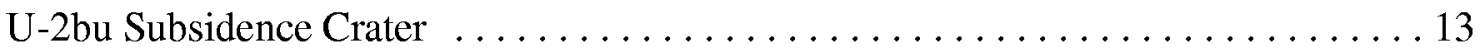

Table 2 - U-2bu Subsidence Crater Verification Sampling Parameters $\ldots \ldots \ldots \ldots \ldots \ldots$

Table 3 - Project Schedule for U-2bu Subsidence Crater Corrective Action $\ldots . \ldots \ldots \ldots 24$ 
THIS PAGE INTENTIONALLY LEFT BLANK 


\section{ACRONYMS AND ABBREVIATIONS}

\begin{tabular}{|c|c|}
\hline $\mathrm{BN}$ & Bechtel Nevada \\
\hline CFR & Code of Federal Regulations \\
\hline DOE & U.S. Department of Energy \\
\hline $\mathrm{DOE} / \mathrm{NV}$ & U.S. Department of Energy, Nevada Operations Office \\
\hline EPA & U.S. Environmental Protection Agency \\
\hline FFACO & Federal Facility Agreement and Consent Order \\
\hline $\mathrm{ft}$ & foot \\
\hline JHA & Job Hazard Analysis \\
\hline LDR & Land Disposal Restrictions \\
\hline $\mathrm{m}$ & meter \\
\hline $\mathrm{mg} / \mathrm{kg}$ & milligram per kilogram \\
\hline $\mathrm{mg} / \mathrm{L}$ & milligram per liter \\
\hline $\mathrm{mL}$ & milliliter \\
\hline $\mathrm{mm}$ & millimeter \\
\hline NAC & Nevada Administrative Code \\
\hline NDEP & Nevada Division of Environmental Protection \\
\hline NTS & Nevada Test Site \\
\hline NTSWAC & Nevada Test Site Waste Acceptance Criteria \\
\hline PEER & PEER Consultants \\
\hline PPE & Personal Protective Equipment \\
\hline
\end{tabular}




\section{ACRONYMS AND ABBREVIATIONS (Continued)}

RCRA Resource Conservation and Recovery Act

REECo Reynolds Electrical and Engineering Co., Inc.

RWP Radiological Work Permit

SSHASP Site-Specific Health and Safety Plan

TCLP Toxicity Characteristic Leachate Procedure

TPH Total Petroleum Hydrocarbon 


\section{EXECUTIVE SUMMARY}

The U-2bu subsidence crater, Corrective Action Unit 109, will be closed in accordance with the Resource Conservation and Recovery Act, the Nevada Division of Environmental Protection operational permit, and the Federal Facility Agreement and Consent Order. The U-2bu subsidence crater is located in Area 2 of the Nevada Test Site. It was created in 1971 by an underground nuclear test with the name Miniata. The crater has a diameter of 288 meters ( 944 feet) and an approximate depth of 35 meters (115 feet).

The subsidence crater was used as a land disposal unit for radioactive and hazardous waste from 1973 to 1988. Site disposal history is supported by memorandums, letters, and personnel who worked at the Nevada Test Site at the time of active disposal. Waste disposal into the crater was officially discontinued in March 1989.

Based on the results of the analyses reported in the site characterization report, the only constituents of concern in the U-2bu subsidence crater include leachable lead and total petroleum hydrocarbons. Leachable lead was detected at a concentration of 5.7 milligrams per liter at the top of the crater. This concentration exceeds the Title 40 Code of Federal Regulations 261.24 level of 5.0 milligrams per liter and, therefore, will require removal. Low levels of petroleum hydrocarbons in the diesel range were found in samples at the bottom of the crater. Maximum results were 190 milligrams per kilogram. Information is provided in this Closure Plan for the Nevada Division Environmental Protection to determine if corrective action is required under Nevada Administrative Code 445A.227, or if concentrations detected are acceptable for closure in place based on minimal risk.

Closure activities will include the excavation and disposal of impacted soil from the top of the crater. The soil is anticipated to be disposed of as mixed waste due to the presence of both radioactive and Resource Conservation and Recovery Act hazardous constituents. In addition, metal debris in the vicinity of the impacted soil will be surveyed to determine if it has been impacted by any radiological constituents. All waste will be disposed of in accordance with the proper regulations.

Upon completion of excavation, verification samples will be collected to show that the leachable lead has been removed to concentrations below the regulatory action level. After sample results show that the lead has been removed, the excavated area will be backfilled and a soil flood diversion berm will be constructed as a best management practice. An independent registered professional engineer will certify the site was closed following the approved Closure Plan. Post-closure care is not warranted for this site because closure activities will involve removal of the Resource Conservation and Recovery Act constituents of concern. 
THIS PAGE INTENTIONALLY LEFT BLANK 


\subsection{INTRODUCTION}

The U-2bu subsidence crater is an historic disposal unit located in Area 2 of the Nevada Test Site (NTS) (Figure 1). The Federal Facility Agreement and Consent Order (FFACO) lists the U-2bu subsidence crater as Corrective Action Unit 109 and Corrective Action Site 02-08-01 (FFACO, 1996). Remediation of the U-2bu subsidence crater is required under the Resource Conservation and Recovery Act (RCRA) operational permit, which is the Permit for a Hazardous Waste Facility, Permit Number NEV HW009 (Nevada Division of Environmental Protection [NDEP], 1995), and the FFACO (FFACO, 1996).

The U-2bu subsidence crater was created in 1971 by an underground nuclear test with the name Miniata. The crater has a diameter of 288 meters $(\mathrm{m})$ (944 feet [ft]) and an approximate depth of $35 \mathrm{~m}$ (115 ft) (Figure 2).

The subsidence crater was used as a land disposal unit for radioactive and hazardous waste from 1973 to 1988. The site disposal history is supported by memorandums, letters, and personnel who worked at the NTS at the time of active disposal. Wastes included radioactive-impacted drilling mud that also contained chromium and possibly lead. Drilling mud was collected in a vacuum truck, transported to $\mathrm{U}-2 \mathrm{bu}$, and dumped into the crater from the northern rim. The vacuum trucks were rinsed with water, which was also disposed in the crater. NTS personnel report that drilling mud from the Baneberry test cleanup and the Area 9 Integrated Test Series, including the Avens-Cream test, were disposed in U$2 \mathrm{bu}$. The total volume of drilling mud and associated rinsate disposed at U-2bu is unknown.

In addition to the drilling mud, 13,000 to 19,000 liters (3,500 to 5,000 gallons) of wastewater and sludge from the Area 6 Decontamination Facility sumps were disposed in U-2bu in November 1988. The wastewater contained solvents and mixed fission products. This was the last waste disposed into U-2bu. Previous disposal of mixed hazardous and radioactive waste from the Decontamination Facility into the crater is undocumented, although personnel working at the facility at the time have stated that previous disposal activities of waste from the Decontamination Facility did take place into U-2bu. The volumes of waste disposed are unknown, however, the waste stream was likely similar to the wastewater and sludge disposed in November 1988. According to a Reynolds Electrical and Engineering Co., Inc. (REECo) memorandum, waste disposal into the crater was officially discontinued in March 1989.

Disposal of waste into the crater has resulted in the development of an erosion gully on the northeast side of the crater running from the top of the crater to an artificial alluvial fan that has formed at the bottom. Historical aerial photographs of the U-2bu subsidence crater show that the fan has grown over the years in association with the disposal of waste. The areal extent of the fan is currently 800 square meters (8,600 square feet) (U.S. Department of Energy [DOE], 1998b). 




\subsection{PURPOSE}

The purpose of this Closure Plan is to provide the strategy to close the CAU 109. The only previous characterization activities at U-2bu were conducted in April 1998 and involved the collection of surface and subsurface soil sampling from the north crater rim, the crater bottom, sides, gully, and artificial alluvial fan (DOE, 1998b) (Figure 2).

Soil samples were analyzed for the following:

C Total petroleum hydrocarbons (TPH) in both the gasoline and diesel range

C Toxicity Characteristic Leachate Procedure (TCLP) metals

C Total and TCLP volatile organic compounds and semivolatile organic compounds

C Polychlorinated biphenyls

C Gamma scan and gross alpha/beta

Based on the results of these analyses reported in the site characterization report (DOE, 1998b), the only constituents of concern in the U-2bu subsidence crater include TCLP (leachable) lead and petroleum hydrocarbons. All other potential constituents of concern were below the U.S. Environmental Protection Agency (EPA) Region IX Preliminary Remediation Goals (EPA, 1996a), and the RCRA toxicity characteristics levels established in Title 40 Code of Federal Regulations (CFR) 261.24 (EPA, 1996c). As part of the Data Quality Objective process, and later in the approved Characterization Report (DOE, 1998b), the radiological constituents were not considered constituents of concern at this site. Radiological constituents are only a concern for waste disposal purposes.

Leachable lead was detected at a concentration of 5.7 milligrams per liter $(\mathrm{mg} / \mathrm{L})$ at the top of the crater, just above the erosion gully. This concentration exceeds the Title 40 CFR 261.24 (EPA, 1996c) TCLP level of $5.0 \mathrm{mg} / \mathrm{L}$ for lead and, therefore, requires removal. Once the lead is removed, the RCRA closure requirements for the site will be met per $\S 270.1$ (c)(5 \& 6) (EPA, 1996h).

Total petroleum hydrocarbons in the diesel range were found in one sample and its duplicate at the bottom of the crater at a maximum concentration of 190 milligrams per kilogram $(\mathrm{mg} / \mathrm{kg})$. This result exceeds the $100 \mathrm{mg} / \mathrm{kg}$ action level established in the Nevada Administrative Code (NAC) 445A.227 (NAC, 1996a). However, because the unit is located in a remote, arid environment with a deep water table, and the hydrocarbon is present in low levels that are isolated in the bottom of the crater, this portion of the site should be considered for administrative closure. Detailed information is provided in Appendix A in the "A through K" assessment of risk (NAC, 1996b) that shows that the level of petroleum hydrocarbons present in the U-2bu subsidence crater does not pose a risk to human health and the environment. 


\subsection{SCOPE}

The scope of work for this project consists of the following activities:

C Preplanning and site preparation, including the preparation of all plans and permits, and mobilization of equipment to the site.

C Excavation of the lead impacted soil near the top of the crater.

C Collection of soil samples to verify that lead has been removed to approved levels.

C Decontamination of equipment used to excavate the soil.

C Backfilling the excavated areas.

C Constructing a soil berm as a best management practice to prevent preferential run-on into the erosion gully.

C Removal of the current posting and chain link fencing and restoration of the crater fencing and radiological postings.

C Disposal of excavated materials following applicable federal, state, and DOE regulations in accordance with Section 2.3 of this Closure Plan.

The characterization, handling, shipping, and certification of the impacted soil and other waste will be conducted according to the waste profile developed under the requirements of the Nevada Test Site Waste Acceptance Criteria (NTSWAC) (DOE, 1996a) and the Bechtel Nevada Waste Certification Program Plan for Radioactive Waste Storage of Disposal (Bechtel Nevada [BN], 1996a) as appropriate. Waste control and certification activities will be subject to a U.S. Department of Energy, Nevada Operations Office (DOE/NV) Radioactive Waste Acceptance Program approval process.

\subsection{CLOSURE PLAN CONTENTS}

This document is divided into the following sections in accordance with the approved FFACO Closure Plan outline:

C Section 1.0 - Introduction

C Section 2.0 - Detailed Statement of Work 
U-2bu Subsidence Crater Section:

INTRODUCTION

C Section 3.0 - Schedule

C Section 4.0 - Post-Closure Plan

C Section 5.0 - References 


\subsection{DETAILED STATEMENT OF WORK}

\subsection{CLOSURE APPROACH}

This section describes the closure methodology for the U-2bu subsidence crater. Closure will be accomplished following the conditions of Title 40 CFR $§ 270.1$ (EPA, 1996h).

\subsubsection{Preplanning and Site Preparation}

Prior to beginning closure activities, several planning and preparation activities must be accomplished. These activities include document, plan, and site preparation, as well as delineation of the leadimpacted soil that will require excavation.

\subsubsection{Site-Specific Health and Safety Plan/Job Hazard Analysis}

A Site-Specific Health and Safety Plan (SSHASP) and Job Hazard Analysis (JHA) has been prepared and approved. A copy of the document will be kept on-file in the BN Environmental Restoration and the BN Environmental, Safety, and Health Division offices in Mercury, Nevada. The original document will be kept by the site supervisor at the work site. The SSHASP and JHA will be available on-site for review and signature by all workers prior to beginning work at the site. The SSHASP provides a detailed, job-specific plan covering protection against accidents or exposure of workers to contamination. It also discuss weather/air monitoring, accident reporting, emergency procedures, and physical and environmental hazards. The work will also be performed in accordance with the DOE/NV Environmental Restoration Project Health and Safety Plan (DOE, 1998c) and the BN Environmental, Safety, Security, and Health Manual. In addition, the project specific material safety data sheets will be maintained by the Health and Safety Officer and be available on-site. A Contingency Plan has also been prepared that addresses emergency response situations. A copy of the Contengency Plan is provided in Appendix B.

\subsubsection{Field Management Plan}

A Field Management Plan will be prepared for the closure activities. The plan will outline how the work will be accomplished and provide a detailed schedule for the project. In addition, it will identify the responsible parties for each aspect of the project and determine how decisions will be made. A copy of the Field Management Plan will be placed on file at the BN Environmental Restoration Office in Mercury, Nevada, and a copy will also be available at the project field site. 


\subsubsection{National Environmental Policy Act Documentation}

A National Environmental Policy Act checklist has been completed. A biologic survey was performed to report on the condition of existing trees, shrubs, grassed areas, and wildlife immediately adjacent to the area which may be affected by construction activities, equipment and material storage areas, and access routes. Based on the findings of this survey, the excavation activities at the U-2bu subsidence crater will not affect any biological resources. Closure activities at the site will follow all applicable federal, state, and local laws, regulations, and permits for protection of the environment.

\subsubsection{Pre-Excavation Activity Geoprobe ${ }^{\circledR}$ Sampling}

Site characterization indicated that leachable lead was found in Sample U2BU101 (Figure 2) at a depth of $1.2 \mathrm{~m}$ (4 ft). In February, soil samples were collected from five locations around site characterization sample U2BU101. The locations of these samples are provided in Figure 3. The samples will be used to more accurately outline the expected boundaries of impacted soil and potentially limit the size of the closure excavation. Limiting the size of the excavation will minimize the amount of waste to be generated and disposed during closure.

The samples were collected using a Geoprobe ${ }^{\circledR}$ by pushing a $1.2-\mathrm{m}$ (4-ft) by 38 -millimeter $(\mathrm{mm})(1.5$-inch) core barrel to a maximum depth of $3 \mathrm{~m}(10 \mathrm{ft})$ below site grade. Soil samples were collected from the intervals of $0-0.3 \mathrm{~m}, 1.2-1.5 \mathrm{~m}, 1.8-2.1 \mathrm{~m}$, and $2.7-3 \mathrm{~m}(0-1 \mathrm{ft}, 4-5 \mathrm{ft}, 6-7 \mathrm{ft}$, and 9-10 ft). Samples are being analyzed using EPA Method, SW-846 1311/6010/7470 for TCLP metals (EPA, 1996i). To determine if the waste will be disposed as mixed waste, soil samples are also being analyzed for radiological constituents to ascertain if the levels are above the Nevada Test Site Performance Objective for Certification of Nonradioactive Hazardous Waste (REECo, 1995). If Americium is identified from the Gamma Scan, then isotopic analysis for Plutonium will be completed. Quality control samples were collected in accordance with the Nevada Environmental Restoration Project. Industrial Sites, Quality Assurance Project Plan (DOE, 1996b) such that one duplicate and one equipment blank were collected for the sampling activity.

Soil samples were also collected from the borrow pit located adjacent to the U-2bu subsidence crater. Due to the historical use of the land for weapons testing and related activities in this part of the NTS, these samples will serve to determine if the soil in the borrow pit is clean and can be used for backfill material. Unlike the Geoprobe ${ }^{\circledR}$ samples, these samples were collected using a stainless steel scoop from the upper $0-0.15 \mathrm{~m}(0-0.5 \mathrm{ft})$ and are only being analyzed for radiological constituents. 


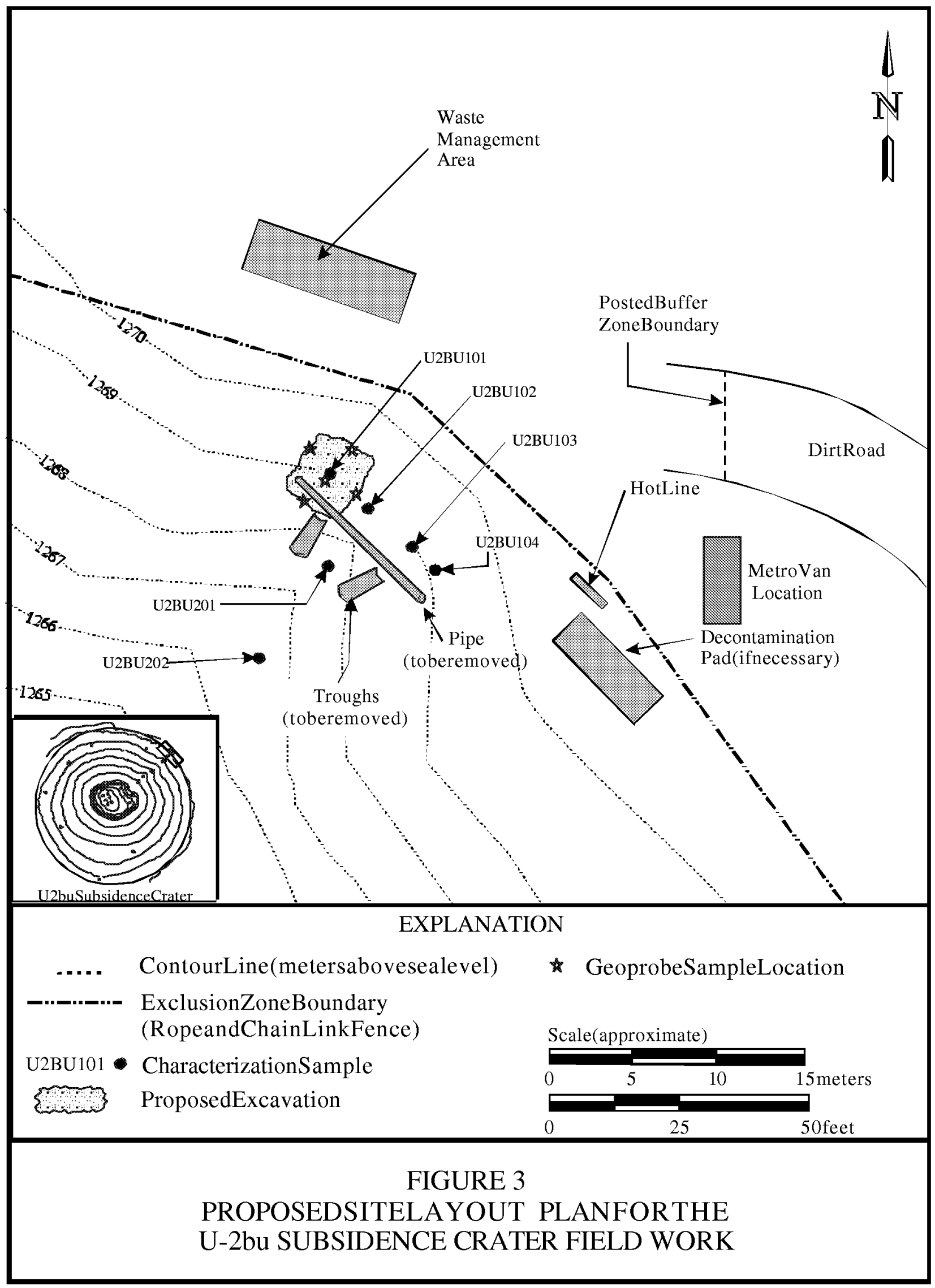




\subsubsection{Site Preparation}

Site preparation involves regrading and improving the road leading to the crater, mobilization of equipment to the site, designation of the exclusion zone, contamination reduction zone, decontamination area, and waste management area. A proposed site layout is provided as Figure 3. This proposed layout is to be used for planning purposes only and may change depending on conditions at the time field work begins. A piece of steel piping approximately $9 \mathrm{~m}(30 \mathrm{ft})$ long and two steel troughs used in the discharge of waste into the crater will be removed from the top of the crater. This debris will be surveyed and swiped for radiological analysis and managed in accordance with Section 2.3 of this Closure Plan.

\subsubsection{Field Activities}

\subsubsection{Excavation of the Lead-Impacted Soil}

Until analytical results confirm the area of soil impacted by lead, the volumes of soil to be excavated are unknown. The area to be excavated will be delineated by the results of the Geoprobe $^{\circledR}$ sampling of the impacted area. Based on the current knowledge of the site, the excavation will be a minimum of $1.5 \mathrm{~m}(5 \mathrm{ft})$ deep and $3 \mathrm{~m}(10 \mathrm{ft})$ long. Data is insufficient to determine the width of the excavation at this time. In addition, the actual depth and length of the excavation may increase after Geoprobe ${ }^{\circledR}$ sampling better delineates the impacted area.

During excavation, the soil and excavated area will be examined visually for stains or discoloration that may be the result of the waste discharged into the crater. The excavation will also be surveyed periodically with a hand-held Electra to identify any radiologically impacted soil as a possible indicator of associated lead. Any areas identified as impacted will be removed.

Based on process knowledge, the soil is expected to be radioactive. If the analytical results from the Geoprobe ${ }^{\circledR}$ sampling confirm this assumption, all excavated soil will be managed as a mixed radiological and hazardous waste. Impacted soil will be placed into B-25 boxes following BN Procedure L-E10.308.WWC, "Radioactive Waste Tracking, Handling, and Management at the NTS," (BN, 1998a) and stored temporarily in a waste management area to await disposal in accordance with Section 2.3 of this Closure Plan. The leachable lead levels in the waste will be evaluated to determine if the waste meets the Land Disposal Restrictions (LDRs). If the leachable lead levels are above the LDRs, the waste will be sent to an off-site contracted treatment facility where it will be treated to meet the LDRs. The treated waste will then be returned to the NTS for disposal.

Verification sampling will be done after all impacted soil is believed to have been removed. Sampling will be conducted in accordance with Section 2.4 of this Closure Plan. Collected samples will be analyzed for TCLP metals, because lead is the only constituent of concern for this site. The excavation will remain open until the results of verification samples show that 
clean-up levels have been met and no additional excavation is required. Berms will be placed on the upgradient side of the excavation to prevent flooding of the excavation by run-off.

\subsubsection{Decontamination of Equipment}

All equipment and materials used on-site will be surveyed for radiological constituents using handheld Electras and swipe samples prior to release from the site. Geoprobe ${ }^{\circledR}$ sampling equipment will be decontaminated between samples. The decontamination rinsate that is collected will be placed in a 208-L (55-gallon) drum. Any equipment that becomes contaminated during the excavation process will be decontaminated on-site. For larger pieces of equipment that cannot be decontaminated over a 208-L (55-gallon) drum, a decontamination pad will be established by lining a bermed area large enough to hold a piece of heavy equipment. The equipment will be driven onto the pad and steam cleaned. Hand-held equipment will be cleaned with a solution of Alconox $^{\mathrm{TM}}$ and water, and rinsed with clean water. Rinsate will be held in the bermed area and allowed to evaporate unless it is in excess of what the bermed area can hold. Excess rinsate will be pumped into drums. Any remaining rinsate at the time of final site housekeeping will be placed in containers and disposed of following Section 2.3 of this Closure Plan. The plastic liner will be placed in containers as compactable waste and disposed of in accordance with Section 2.3.

\subsubsection{Construction of Berm}

A soil berm will be constructed upgradient of the erosion gully that drains into the crater. This berm will divert run-on away from the erosion gully, which provides preferential drainage into the crater. This gully formed as a result of the disposal practices at the crater and is not aligned with the natural drainage around the crater. In addition, a borrow pit that is approximately $150 \mathrm{~m}(500$ $\mathrm{ft})$ long, $60 \mathrm{~m}(200 \mathrm{ft})$ wide, and a maximum of $4.5 \mathrm{~m}(15 \mathrm{ft})$ deep, is located approximately $20 \mathrm{~m}$ $(70 \mathrm{ft})$ north of crater. This borrow pit intersects the natural drainage of $\mathrm{U}-2 \mathrm{bu}$ capturing any runon leading toward the crater. The berm is being constructed as a best management practice and is not a regulatory requirement for closure of the site. Based on the information provided in the " $\mathrm{A}$ through K" assessment of risk (Appendix A) and historical photographs of the crater (Appendix C), the collapse zone below the crater is not a preferential pathway for hydrocarbon migration. As a result, the levels of petroleum hydrocarbon in the crater and their potential to migrate to the groundwater will not be impacted by run-on into the crater. Therefore, the berm will not require

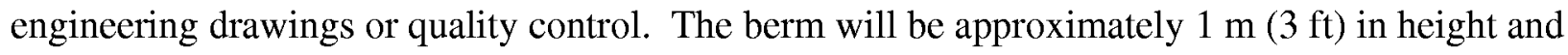
will be constructed of clean soil taken from a nearby borrow pit. 


\subsubsection{Site Restoration}

After confirmatory sampling indicates that the lead-impacted soils have been removed, the excavated area will be refilled with clean fill material to return the site to its original grade. Low areas formed by the preferential drainage formed by historical disposal practices will be filled to mound above the surrounding grade in order to redirect water run on. All chain-link fencing will be removed and the existing three-strand wire fencing that is necessary around all subsidence craters at the NTS will be repaired and restored where it is missing around the crater.

\subsection{CONSTRUCTION QUALITY ASSURANCE/QUALITY CONTROL}

Construction activities primarily consist of excavation and earth moving. As a result, no construction quality assurance/quality control specifications are required.

\subsection{WASTE MANAGEMENT}

Waste from the closure will be managed following Table 1. Potential waste types include lowlevel radioactive waste, hazardous waste, mixed waste, and non-hazardous (sanitary) waste. All waste types that are generated will be managed in a manner that complies with all state and federal regulations, DOE orders, BN procedures, and the RCRA Operational Permit. Non-hazardous waste will be handled in accordance with DOE Standard Operating Procedure ERD-05-210, "Management and Minimization of Nonhazardous Waste at the Nevada Test Site for the Nevada Environmental Restoration Project" (DOE, 1994a). If the waste is determined to be hazardous waste, it will be handled in accordance with DOE Standard Operating Procedure ERD-05-211, "Management and Minimization of Hazardous Waste at the Nevada Test Site for the Nevada Environmental Restoration Project" (DOE, 1994b). All low-level radioactive waste and mixed waste containers will be packaged, managed, tracked, and stored according to BN Procedure L-E10.308.WWC, "Radioactive Waste Tracking, Handling, and Management at the NTS" (BN, 1998a). If necessary, a Waste Profile and Material Evaluation Form will be prepared in accordance with the NTSWAC (DOE, 1996a) and BN Procedure L-E10.302.P, "Radioactive Waste Evaluation," (BN, 1996b) based on previous site characterization results.

The only confirmed hazardous constituent of concern is leachable lead, therefore, the waste will be managed as hazardous waste (D008). Process knowledge regarding the waste disposed at the U2 bu subsidence crater indicates that radiological constituents are probably present at the site. Therefore, the samples collected by the Geoprobe ${ }^{\circledR}$ will also be analyzed for radioisotopes for waste characterization purposes. If the soil is found to contain added radioactivity above the Performance Objective Criteria for certification of nonradioactive waste (REECo, 1995), the waste will be managed and disposed of as a mixed waste. 
TABLE 1- MANAGEMENT OF VARIOUS WASTE TYPES TO BE PRODUCED AT THE U-2BU SUBSIDENCE CRATER

\begin{tabular}{|c|c|c|}
\hline MEDIA & WASTE TYPE & DECISION \\
\hline \multirow{4}{*}{$\begin{array}{l}\text { Impacted Soil and } \\
\text { Metal Debris }\end{array}$} & Low-Level Radioactive Waste & $\begin{array}{l}\text { Low level waste will be managed in accordance with the BN Procedure L-E10.308. WWC, } \\
\text { "Radioactive Waste Tracking, Handling, and Management at the NTS" (BN, 1998a). Waste will be } \\
\text { placed into containers, labeled, and placed in the designated waste management area. If } \\
\text { necessary, absorbent will be added. Appropriate paperwork (Package Inventory, Waste Traveler, } \\
\text { Packaging Certification, Radioactive Material Shipping Exception Record or Radioactive Material } \\
\text { Shipping Record, Waste Shipment Checklist, and Certification Statement) will be completed prior } \\
\text { to shipment for disposal. }\end{array}$ \\
\hline & $\begin{array}{l}\text { RCRA-Regulated Hazardous } \\
\text { Waste }\end{array}$ & $\begin{array}{l}\text { Waste will be managed in accordance with the DOE Standard Operating Procedure } \\
\text { ERD-05-211, "Management and Minimization of Hazardous Waste at the Nevada Test Site for the } \\
\text { Nevada Environmental Restoration Project" (1994b). Waste will be placed into containers, } \\
\text { labeled, and placed in the designated waste management area where it will be inspected weekly } \\
\text { until the time of disposal. }\end{array}$ \\
\hline & Mixed waste & $\begin{array}{l}\text { Waste will be managed in accordance with BN Procedure L-E10.308.WWC, "Radioactive Waste } \\
\text { Tracking, Handling, and Management at the NTS" (BN, 1998a). Waste will be placed into } \\
\text { containers, labeled, and placed in the designated waste management area where it will be } \\
\text { inspected weekly until the time of disposal. If necessary, absorbent will be added. If the waste } \\
\text { does not meet the LDRs, it will be shipped to an off-site treatment facility for treatment prior to } \\
\text { disposal at the NTS. Appropriate paperwork (Package Inventory, Waste Traveller, Packaging } \\
\text { Certification, Radioactive Material Shipping Exception Record or Radioactive Material Shipping } \\
\text { Record, Waste Shipment Checklist, Certification Statement, and NTS Onsite Waste Transport } \\
\text { Manifest) will be completed prior to shipment for treatment or disposal. }\end{array}$ \\
\hline & $\begin{array}{l}\text { Levels Less Than Regulated } \\
\text { Limits }\end{array}$ & The soil will be returned to excavation and used a backfill material. \\
\hline
\end{tabular}


TABLE 1 (Cont.) - MANAGEMENT OF VARIOUS WASTE TYPES TO BE PRODUCED AT U-2BU SUBSIDENCE CRATER

\begin{tabular}{|c|c|c|}
\hline MEDIA & WASTE TYPE & DECISION \\
\hline \multirow{4}{*}{$\begin{array}{l}\text { Decontamination } \\
\text { Rinsate and Liner }\end{array}$} & Low-Level Radioactive Waste & $\begin{array}{l}\text { Waste will be managed in accordance with the BN Procedure L-E10.308.WWC, "Radioactive Waste } \\
\text { Tracking, Handling, and Management at the NTS" (BN, 1998a). Waste will be solidified using Aqua- } \\
\text { Set }{ }^{\mathbb{( \mathbb { }}} \text { or an equivalent approved solidification agent, placed into containers, labeled, and placed in } \\
\text { the designated waste management area. Appropriate paperwork (Package Inventory, Waste } \\
\text { Traveller, Packaging Certification, Radioactive Material Shipping Exception Record or Radioactive } \\
\text { Material Shipping Record, Waste Shipment Checklist, and Certification Statement) will be completed } \\
\text { prior to shipment for disposal. }\end{array}$ \\
\hline & $\begin{array}{l}\text { RCRA-Regulated Hazardous } \\
\text { Waste }\end{array}$ & $\begin{array}{l}\text { Waste will be managed in accordance with the DOE Standard Operating Procedure ERD-05-211, } \\
\text { "Management and Minimization of Hazardous Waste at the Nevada Test Site for the Nevada } \\
\text { Environmental Restoration Project" (DOE, 1994b). Waste will be solidified, placed into containers, } \\
\text { labeled, and placed in the designated waste management area where it will be inspected weekly until } \\
\text { the time of disposal. }\end{array}$ \\
\hline & Mixed Waste & $\begin{array}{l}\text { Waste will be managed in accordance with BN Procedure L-E10.308.WWC, "Radioactive Waste } \\
\text { Tracking, Handling, and Management at the NTS" (BN, 1998a). Waste will be solidified, placed into } \\
\text { containers, labeled, and placed in the designated waste management area where it will be inspected } \\
\text { weekly until the time of disposal. Appropriate paperwork (Package Inventory, Waste Traveller, } \\
\text { Packaging Certification, Radioactive Material Shipping Exception Record or Radioactive Material } \\
\text { Shipping Record, Waste Shipment Checklist, Certification Statement, and NTS Onsite Waste } \\
\text { Transport Manifest) will be completed prior to shipment for disposal. }\end{array}$ \\
\hline & $\begin{array}{l}\text { Levels Less Than Regulated } \\
\text { Limits }\end{array}$ & $\begin{array}{l}\text { Waste will be allowed to evaporate or solidified, if necessary, and subsequently transported to the } \\
\text { Area 9, U10C Landfill for disposal. }\end{array}$ \\
\hline
\end{tabular}




\section{TABLE 1 (Cont.) - MANAGEMENT OF VARIOUS WASTE TYPES TO BE PRODUCED AT U-2BU SUBSIDENCE} CRATER

\begin{tabular}{|c|c|c|}
\hline MEDIA & WASTE TYPE & DECISION \\
\hline \multirow{4}{*}{$\begin{array}{l}\text { Personal } \\
\text { Protective } \\
\text { Equipment (PPE) } \\
\text { and Sampling } \\
\text { Equipment }\end{array}$} & $\begin{array}{l}\text { Low-Level Radioactive Waste } \\
\text { (Based on Field-Screening } \\
\text { Background Levels) }\end{array}$ & $\begin{array}{l}\text { Waste will be managed in accordance with the BN Procedure L-E10.308.WWC, "Radioactive Waste } \\
\text { Tracking, Handling, and Management at the NTS" (BN, 1998a). PPE generated in association with a } \\
\text { hotline will also be managed in accordance with BN Procedure L-A14.107.H, "General Radiological } \\
\text { Control Technician Field Instructions" (BN, 1998b). PPE will be placed in the containers of soil to } \\
\text { occupy any void space in the container. }\end{array}$ \\
\hline & RCRA-Regulated Hazardous & $\begin{array}{l}\text { Waste will be managed in accordance with the DOE Standard Operating Procedure ERD-05-211, } \\
\text { "Management and Minimization of Hazardous Waste at the Nevada Test Site for the Nevada } \\
\text { Environmental Restoration Project" (DOE, 1994b). Waste will be placed into containers, labeled, and } \\
\text { placed in the designated waste management area where it will be inspected weekly until the time of } \\
\text { disposal. }\end{array}$ \\
\hline & Mixed Waste & $\begin{array}{l}\text { Waste will be managed in accordance with BN Procedure L-E10.308.WWC, "Radioactive Waste } \\
\text { Tracking, Handling, and Management at the NTS" (BN, 1998a). PPE will be placed in the containers } \\
\text { of soil to occupy any void space in the container. }\end{array}$ \\
\hline & $\begin{array}{l}\text { Levels Less Than Field- } \\
\text { Screening Background Levels }\end{array}$ & Waste will be managed as sanitary waste and transported to the Area 9, U10C Landfill for disposal. \\
\hline
\end{tabular}




\subsubsection{Container Management}

All containers will be handled following Title 40 CFR $\S 262.34$ (EPA, 1996d) and Subpart I of Title 40 CFR $§ 265$ (EPA, 1996f) which specifies the use and management of containers. All containers will be in good condition (no significant rust or dents) and will only be filled 7/8 of the maximum capacity of the container. If the container begins to leak, the contents will be transferred to a container that is in good condition. The containers will be lined or made of a material that will not react with the waste. The containers will always be closed while stored unless waste is added or removed and will be handled in such a manner that will not jeopardize the integrity of the container. All drums and containers will be locked before the end of each workday.

The B-25 boxes to be used during this project will be filled to meet their weight capacity, which is anticipated to be 3,600 kilograms (8,000 pounds). When the boxes have almost reached their weight capacity, compactable waste will be placed in the B-25 boxes to fill any existing void spaces. After a box has been filled, the waste package will be closed according to BN Procedure L-E10.308.WWC, "Radioactive Waste Tracking, Handling, and Management at the NTS" (BN, 1998a). If a box is not completely filled to capacity at the end of a workday, the lid will be closed without securing the clips and tamper-resistant tape will be placed on the box.

A secondary containment system will only be required if the containers hold free liquid or are unprotected from contact with accumulated liquid. Because the majority of the waste produced during this project is anticipated to be soil and debris, secondary containment will not be required. If, however, free liquid is placed into containers, such as the decontamination water, it will be placed on spill containment pallets.

Appropriate labels and relevant information will be marked on each container with an indelible marker and be legible and clearly visible for inspections. Pertinent data may be written on duct tape or a blank adhesive label that is applied to the side of the container.

The following information will be included:

C Waste-tracking label.

C Type of waste in the container (i.e., it must be marked "Hazardous Waste").

C Location waste was derived from.

C Date accumulation begins/ends.

C "Awaiting Analysis" sticker after sampling has been completed, if sampling is required. 


\subsubsection{Site Control}

A fenced hazardous waste storage area will be established outside of the work area to store material that could potentially be RCRA-regulated, low-level radioactive waste, or mixed waste. This will consist primarily of the B-25 containers. Figure 3 shows the planned location for the waste management area. This location may change as field conditions dictate.

\subsubsection{Preparedness and Prevention}

Under Title 40 CFR $§ 265$, Subpart C (EPA, 1996f), all hazardous waste facilities must be maintained and operated in a manner that minimizes the possibility of fire, explosion, or any unplanned event. Hazards posed by the waste stored at the facility do not require a specific kind of equipment; however, fire extinguishers will be available in all vehicles on-site. Two-way radios will be available in field vehicles or as hand-held types.

Aisle space between containers must be sufficient to allow the unobstructed movement of personnel, fire protection equipment, spill control equipment, and decontamination equipment to any area of the facility in the event of an emergency.

NTS Emergency Response Teams, Fire Department, and the Nye County Sheriff's office will be provided a map with a summary of site information. Mercury Medical will be informed of the type of injury or illness that could result from fires, explosions, or releases at the facility. The work site is a remote location in Area 2 of the NTS. The closest emergency services support is located in Area 6, approximately 22 kilometers (14 miles) south of the site.

\subsubsection{Contingency Plan}

As required under Title 40 CFR $\S 265$, Subpart D (EPA, 19961), a contingency plan must be designed to minimize hazards to human health or the environment in the event of fire, explosion, or any unplanned or non-sudden release of hazardous waste constituents. The provisions of the plan must be carried out immediately after such an event and provide actions that facility personnel must take. A copy of the contingency plan is provided in Appendix B.

A copy of the contingency plan and all revisions will be maintained at the facility and provided to the NTS Fire Department, Medical Facilities, and Emergency Response Teams. There must be at least one employee either on the facility premises or on call at all time. This person must have the authority to commit the resources needed to carry out the contingency plan. The emergency coordinator must have thorough knowledge of all aspects of the contingency plan, all operations and activities at the facility, the location and characteristics of the waste handled, the location of the record within the facility, and the facility layout. 


\subsubsection{Personnel Training}

Training for all personnel working at a hazardous waste facility is required as part of Title 40 CFR $\S 265$, Subpart B (EPA, 1996f). The program may be classroom instruction or on-the-job training. On-the-job training must be designed so that personnel are able to respond effectively to emergencies by familiarizing them with emergency procedures, equipment, and systems. All personnel responsible for packing low-level or mixed radioactive waste will be required to read and understand BN Procedure L-E10.308.WWC, "Radioactive Waste Tracking, Handling, and Management at the NTS" (1998a). The operators of the facility must maintain the training records at the facility until closure has been completed.

Title 29 CFR $\S 1910.120$ (EPA, 1996b) details the occupational safety and health requirements that will be followed for personnel supporting excavation activities. All personnel will be required to read and understand the SSHASP prior to working at the site. A tailgate safety briefing will be conducted every morning and as needed as activities or circumstances change. In addition, all personnel will require 40-hour Occupational Safety and Health Administration and Radiation Worker II training.

\subsubsection{Inspections}

An inspection of the areas in which the containers are stored will be conducted at least weekly. The purpose is to identify leaking or deteriorating containers due to corrosion or other factors. Unusual circumstances must be reported immediately so that corrective measures can be taken. Completed inspection forms will be maintained in the project file.

\subsubsection{Waste Minimization}

For the duration of the project, site workers will adhere to the principles of the BN Waste Minimization and Pollution Prevention Program. Care will be taken to segregate waste from nonwaste materials if at all possible and avoid cross contamination.

\subsection{CLEAN-UP VERIFICATION}

\subsubsection{Verification Sampling}

Verification sampling is required at the site. A verification program is designed to support the field decision that any remaining constituents of concern are less than remediation standards and provide the regulator with confidence that sufficient samples have been collected to verify that the site has been remediated. For the U-2bu subsidence crater, the Site Characterization Report (DOE, 1998b) indicated that leachable lead is the only RCRA constituent of concern above 
remediation standards and that, although present, radioactive constituents are not a constituent of concern at this site. Therefore, the verification samples will only be analyzed for TCLP metals. The petroleum hydrocarbon in the bottom of the crater is addressed in the information provided in Appendix A supporting an Administrative Closure of the petroleum hydrocarbon impacted portion of the crater. A summary of the type and number of samples to be collected and the analyses to be performed is provided in Table 2. A two-week analytical turnaround time will be requested for all samples.

Samples will be collected from the sidewalls and floor a minimum of every $1.5 \mathrm{~m}(5 \mathrm{ft})$ along the length of the excavation. Both sidewall and bottom samples will be collected from below the depth

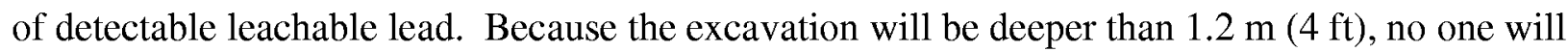
be allowed into the excavation. Therefore, the excavation equipment will scrape the wall or floor, the samples will then be collected as grab samples from the bucket of the excavation equipment and placed in the proper containers (Table 2). All samples will be labeled with a unique sample number and handled under strict chain-of-custody procedures. Verification samples will be analyzed using the analytical methods shown in Table 2.

Samples will be numbered using the following nomenclature:

\section{U2BUSW-N5E}

Where:

C U2BU is the site location

C SW is a sidewall sample (BOT will be used for excavation floor samples)

$\mathrm{C} \quad \mathrm{N}$ is the compass direction of the sidewall (or relative position of excavation floor samples)

C $\quad 5$ is the depth of sample in feet

C E is the relative position of the sidewall sample if more than one sample is collected from the same depth but a different location on the same sidewall

\subsubsection{Quality Control Samples}

One quality control sample (blind replicate) will be collected for every 20 samples collected. Each blind replicate will be labeled with its own distinct sample number so that the laboratory will not be able to readily identify it as a quality control sample. An equipment decontamination blank will also be collected for each sampling event. The data packages provided by the laboratory will be validated and any laboratory method blanks will be evaluated by qualified personnel. 
TABLE 2- U-2BU SUBSIDENCE CRATER VERIFICATION SAMPLING PARAMETERS

\begin{tabular}{|c|c|c|c|c|c|}
\hline PARAMETER & $\begin{array}{l}\text { NUMBER } \\
\text { OF } \\
\text { SAMPLES }\end{array}$ & $\begin{array}{l}\text { NUMBER OF } \\
\text { QUALITY } \\
\text { CONTROI } \\
\text { SAMPLES } \\
\end{array}$ & $\begin{array}{l}\text { SAMPLE } \\
\text { TOTAL }\end{array}$ & ANALYTICAL METHOD & $\begin{array}{c}\text { SAMPLE } \\
\text { CONTAINER }\end{array}$ \\
\hline \multicolumn{6}{|c|}{ Excavated Area } \\
\hline TCLP Metals & $\begin{array}{c}\text { To Be } \\
\text { Determined }\end{array}$ & $\begin{array}{l}1 \text { Blind Replicate and } 1 \\
\text { Equipment Blank for } \\
\text { every } 20 \text { samples } \\
\end{array}$ & $\begin{array}{c}\text { To Be } \\
\text { Determined }\end{array}$ & $\begin{array}{c}\text { SW-846, EPA Method } \\
1311 / 6010 / 7470 \\
(\text { EPA, 1996i) } \\
\end{array}$ & $\begin{array}{l}1-250 \mathrm{~mL} \\
\text { glass jar }\end{array}$ \\
\hline \multicolumn{6}{|l|}{ Metal Debris } \\
\hline $\begin{array}{l}\text { Alpha/Beta } \\
\text { Gamma }\end{array}$ & 50 & N/A & 50 & $\begin{array}{l}\text { 1-minute count } \\
20 \text {-minute count }\end{array}$ & $\begin{array}{l}42.5-\mathrm{mm} \\
\text { diameter filter } \\
\text { paper circle }\end{array}$ \\
\hline \multicolumn{6}{|c|}{ Geoprobe $^{\circledR}$ Samples } \\
\hline TCLP Metals & 20 & $\begin{array}{l}1 \text { Blind Replicate, } \\
1 \text { Equipment Blank }\end{array}$ & 22 & $\begin{array}{c}\text { SW-846, EPA Method } \\
1311 / 6010 / 7470 \\
\text { (EPA, 1996i) }\end{array}$ & $\begin{array}{c}\text { 500-mL nalgene }{ }^{(\mathbb{R}} \\
\text { bottle* }^{*}\end{array}$ \\
\hline $\begin{array}{l}\text { Radioactive Constituents: } \\
\text { Gamma Scan, } \\
\text { Isotopic Plutonium** }\end{array}$ & 20 & $\begin{array}{c}1 \text { Blind Replicate } \\
1 \text { Equipment Blank }\end{array}$ & 22 & $\begin{array}{l}\text { L-E10.602.PC (BN, 1996d) } \\
\text { L-E10.601.PL (BN, 1996c) }\end{array}$ & $\begin{array}{c}\text { 500-mL nalgene } \\
\text { bottle* }^{\circledR} \\
\end{array}$ \\
\hline
\end{tabular}

N/A- Not applicable

* Due to the limited sample recovery of the Geoprobe ${ }^{\circledR}$, both TCLP metals and radioactive constituents will be run from one, 500-milliliter $(\mathrm{mL})$ sample.

** Samples will be analyzed for isotopic plutonium only if the gamma scan indicates an elevated detection of Americium. 


\subsection{PERMITS}

Required permits for this project include a Radiological Work Permit (RWP) and an Excavation and Trenching Permit.

\subsubsection{Radiological Work Permit}

An RWP has been prepared and approved to inform workers of the specific personnel protective equipment necessary to protect them while performing their tasks. The workers will be required to read the permit and acknowledge their understanding of the requirements before entry into the exclusion zone. The RWP will be maintained by the radiological control personnel at the access station. All site workers will be required to be Radiation Worker II-certified.

\subsubsection{Excavating and Trenching Permit}

An approved Excavating and Trenching Permit will be obtained prior to any excavation. The permit contains a justification for the trenching operation and a checklist of pertinent organizations who must inspect the site so that the trenching will not impact utilities. A copy of this permit will be kept at the project site by the site supervisor.

\subsection{CLOSURE CERTIFICATION}

Closure will be verified through appropriate observations and documentation of closure activities. A closure report detailing the closure activities will be prepared and submitted by DOE/NV by certified mail or other means of verifiable delivery to the NDEP. The report will contain:

C Information regarding the volume of impacted material removed from the various components of the unit.

C The disposal history of the impacted soil and other wastes generated during the clean closure of the unit.

C The methodology used and results of verification sampling of the unit. 
C Photographs of closure activities.

C Figures identifying excavation and sample areas.

Included in the closure report will be certification by an Independent, Registered Professional Engineer, and an authorized representative of DOE/NV that the unit has been closed following this plan. The NDEP has waived the Title 40 CFR $\$ 265.115$ (EPA, 1996g) requirement that the certification and closure report be submitted to the NDEP within 60 days of the completion of closure activities. The closure certification and closure report will be delivered by the date specified in Section 3.0. 


\subsection{SCHEDULE}

\subsection{PROJECT SCHEDULE}

A project schedule for the U-2bu subsidence crater closure is provided in Table 3 . The schedule will require modifications if conditions exist that are outside the assumptions on which the schedule is developed. The DOE will keep the NDEP apprised of any conditions that may impact the project schedule. In the event that the project schedule requires modifications, the DOE will consult with NDEP personnel prior to initiating any changes.

\subsection{FIELD WORK CLOSURE SCHEDULE}

The schedule for closure field work for the unit can be found in Table 3 . In general, planned field work consists of the following:

$\begin{array}{lll}\text { C } & \text { Geoprobe }{ }^{\circledR} \text { Sampling } & \text { February } 1999 \\ \text { C } & \text { Preparation for Construction Field Work } & \text { April } 1999 \\ \text { C } & \text { Excavation Activities } & \text { May-June } 1999 \\ \text { C } & \text { Management and Disposal of Waste } & \text { May-September } 1999 \\ \text { C } & \text { Verification Sampling } & \\ & & \end{array}$

Field work will be done in the most efficient manner possible. All verification and waste characterization samples will be submitted for a three-week analytical turnaround. Sufficient flexibility has been placed in the project schedule to account for minor difficulties (weather, equipment breakdown, etc.). The schedule may require modification if conditions exist that are outside the assumptions on which the schedule was developed. 


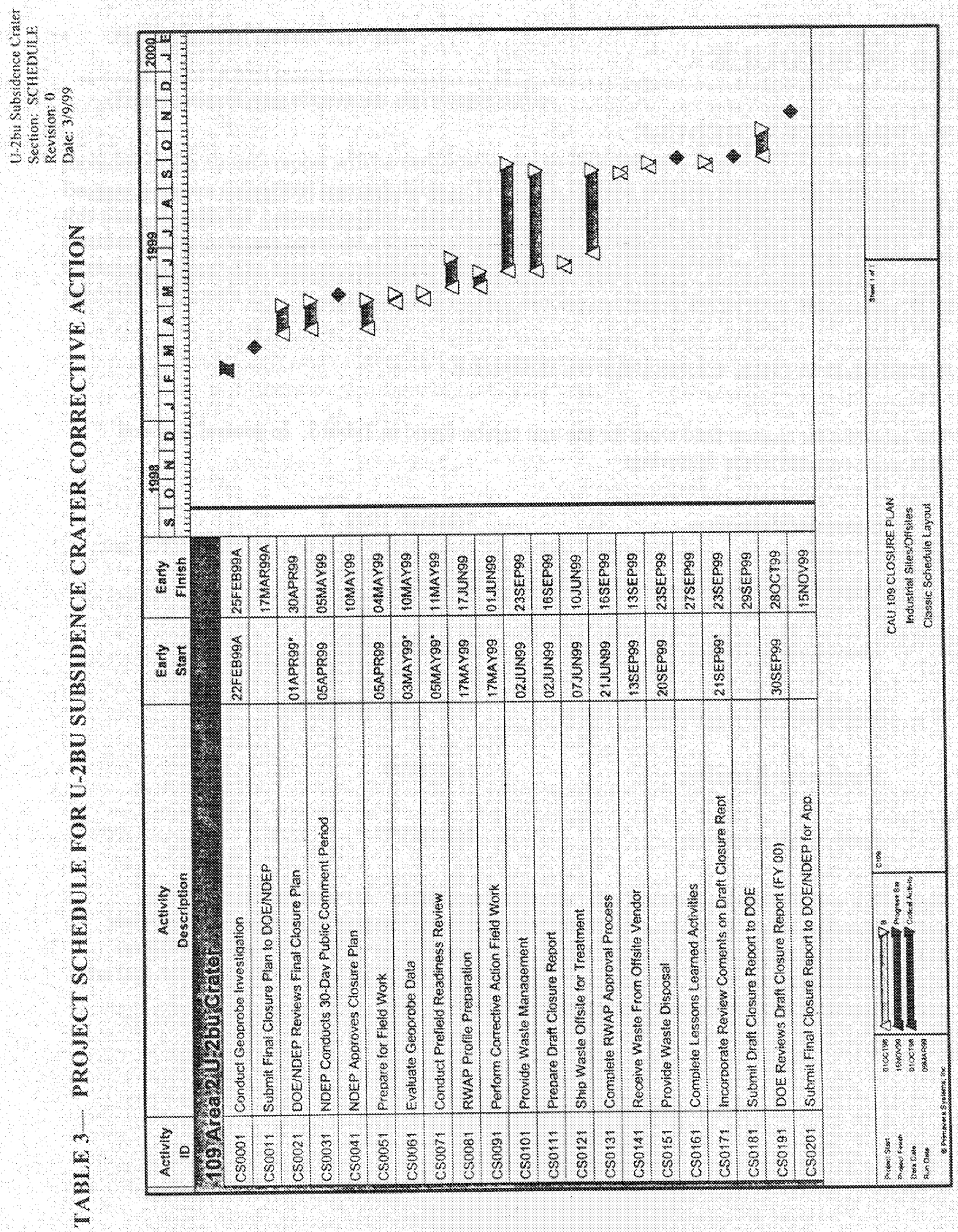




\subsection{POST-CLOSURE PLAN}

Closure of the U-2bu subsidence crater is governed by the RCRA Operational Permit (NDEP, 1995) and the FFACO (1996). This document meets the RCRA Operational Permit requirement for submittal of a Closure Plan to NDEP for approval. The closure of the U-2bu subsidence crater is subject to the conditions of Title $40 \mathrm{CFR} \S 270.1$. Under the conditions of Title 40 CFR $\S 270.1$ (c)(5) and (6) (EPA, 1996h), no post-closure permit is required if it is demonstrated that the closure meets the requirements of Title 40 CFR $\S 264.228$, Title 40 CFR $\S$ 264.280(e) (EPA, 1996e), or Title 40 CFR $\$ 264.258$ (EPA, 1996e), respectively. The level of post-closure care will be determined by demonstration of closure equivalency under Title $40 \mathrm{CFR}$ $\S 270.1$ (c)(5) and (6) (EPA, 1996h). The closure of the U-2bu subsidence crater is expected to meet these requirements and no post-closure care will be required.

\subsection{INSPECTIONS}

During this closure, the RCRA constituents of concern (leachable lead) will be removed to concentrations below the regulatory action level. In addition, the "A through $\mathrm{K}$ " assessment of risk (Appendix A) provides support that conditions at the CAU will not adversely impact human health and the environment. Therefore, inspections will not be required following closure. The land restrictions will be limited to safety restrictions and postings required for all subsidence craters at the NTS.

\subsection{MONITORING}

Based on the "A through $\mathrm{K}$ " assessment of risk (Appendix A), the petroleum hydrocarbons identified in the crater bottom will not impact the groundwater beneath the CAU or any nearby drinking water well. Therefore, post-closure monitoring is not required.

\subsection{MAINTENANCE AND REPAIR}

The only construction planned as part of the closure of the U-2bu subsidence crater is the soil berm to reduce run-on into the crater. This berm is only being constructed as a best management practice and, as a result, maintenance or repairs will not be necessary at the site following closure. 
THIS PAGE INTENTIONALLY LEFT BLANK 


\subsection{REFERENCES}

BN, see Bechtel Nevada.

Bechtel Nevada, 1996a, Waste Certification Program Plan for Radioactive Waste Storage or Disposal at the Nevada Test Site, B-A20/96.03, Revision 1, Las Vegas, NV.

Bechtel Nevada, 1996b, “Radioactive Waste Evaluation,” L-E10.302.P, Las Vegas, NV.

Bechtel Nevada, 1996c, "Detection of Plutonium in Air, Water, and Soil," L-E10.601.PL, Las Vegas, NV.

Bechtel Nevada, 1996d, "Gamma Ray Spectrometry Operations,” L-E10.602.PC, Las Vegas, NV.

Bechtel Nevada, 1998a, "Radioactive Waste Tracking, Handling, and Management at the NTS," L-E10.308.WWC, Las Vegas, NV.

Bechtel Nevada, 1998b, "General Radiological Control Technician Field Instructions" L-A14.107.H, Revision 1, Las Vegas, NV.

DOE, see U.S. Department of Energy.

EPA, see U.S. Environmental Protection Agency.

Federal Facilities Agreement and Consent Order (FFACO) of 1996. Prepared by Nevada Division of Environmental Protection, U.S. Department of Energy, and U.S. Department of Defense.

NAC, see Nevada Administrative Code.

NDEP, see Nevada Division of Environmental Protection.

Nevada Administrative Code, 1996a, NAC 445A, Corrective Action, Carson City, NV. 
Nevada Administrative Code, 1996b, NAC 459.9974, Disposal and Evaluation of Contaminated Soil, Carson City, NV.

Nevada Division of Environmental Protection, 1995, Permit For a Hazardous Waste Facility. Permit Number NEV HW009.

REECo, see Reynolds Electrical and Engineering Co., Inc.

Reynolds Electrical and Engineering Co., Inc., 1995, Nevada Test Site Performance Objective for Certification of Nonradioactive Hazardous Waste, Mercury, NV.

U.S. Department of Energy, Nevada Operations Office, 1989, Offsite Radiation Exposure Review Project, Phase II Soils Programs, Las Vegas, NV.

U.S. Department of Energy, Nevada Operations Office, 1994a, Standard Operating Procedure, "Management and Minimization of Nonhazardous Waste at the Nevada Test Site for the Nevada Environmental Restoration Project," ERD-05-210, September 30, 1994, Las Vegas, NV.

U.S. Department of Energy, Nevada Operations Office, Standard Operating Procedure, 1994b, "Management and Minimization of Hazardous Waste at the Nevada Test Site for the Nevada Environmental Restoration Project," ERD-05-211, September 30, 1994, Las Vegas, NV.

U.S. Department of Energy, Nevada Operations Office, 1994c, Nevada Test Site Grid Map, EG\&G Remote Sensing Laboratory, Las Vegas, NV.

U.S. Department of Energy, Nevada Operations Office, 1996a, Nevada Test Site Waste Acceptance Criteria, Las Vegas, NV.

U.S. Department of Energy, Nevada Operations Office, 1996b, Nevada Environmental Restoration Project. Industrial Sites, Quality Assurance Project Plan, Nevada Test Site. Nevada, Las Vegas, NV.

U.S. Department of Energy, Nevada Operations Office, 1996, Environmental Impact Statement for the Nevada Test Site and Off-Site Locations in the State of Nevada, DOE/EIS 0243, Las Vegas, NV. 
U.S. Department of Energy, Nevada Operations Office, 1998a, RCRA Part A Permit

Characterization Plan for the U-2bu Subsidence Crater, Revision 0, DOE/NV--499, Las Vegas, NV.

U.S. Department of Energy, Nevada Operations Office, 1998b, Characterization Report for Corrective Action Unit 109: Area 2 U-2bu Crater, Nevada Test Site, Nevada, Revision 1, DOE/NV--517, Las Vegas, NV.

U.S. Department of Energy, Nevada Operations Office, 1998c, Nevada Environmental Restoration Project, Health and Safety Plan, Revision 3, Las Vegas, NV.

U.S. Environmental Protection Agency, 1996a, Region IX Preliminary Remediation Goals (PRGs), San Francisco, CA.

U.S. Environmental Protection Agency, 1996b, Title 29 Code of Federal Regulations 1910.120, "Hazardous Waste Operations and Emergency Response," Washington, D.C.

U.S. Environmental Protection Agency, 1996c, Title 40 Code of Federal Regulations 261.24, “Toxicity Characteristic," Washington, D.C.

U.S. Environmental Protection Agency, 1996d, Title 40 Code of Federal Regulations 262.34, “Accumulation Time," Washington, D.C.

U.S. Environmental Protection Agency, 1996e, Title 40 Code of Federal Regulations 264.228, 264.258, 264.280, "Closure and Post-Closure Care," Washington, D.C.

U.S. Environmental Protection Agency, 1996f, Title 40 Code of Federal Regulations 265, "Interim Status Standards for Owners and Operators of Hazardous Waste Treatment, Storage, and Disposal Facilities," Washington, D.C.

U.S. Environmental Protection Agency, 1996g, Title 40 Code of Federal Regulations 265.115, "Certification of Closure," Washington, D.C.

U.S. Environmental Protection Agency, 1996h, Title 40 Code of Federal Regulations 270.1, "EPA Administered Permit Programs: The Hazardous Waste Permit Program, Subpart A - General Information," Washington, D.C.

U.S. Environmental Protection Agency, 1996i, Test Methods for Evaluating Solid Waste Physical/Chemical Methods (SW-846). Third Edition, Washington, D.C. 
APPENDIX A

“A THROUGH K" EVALUATION 
One of the state regulatory requirement affecting the closure of the $\mathrm{U}-2 \mathrm{bu}$ subsidence crater is the requirement of NAC 445A.227 (NAC, 1996), Contamination of Soil: Order by Director for Corrective Action: Factors to be Considered in Determining Whether Corrective Action is Required, referred to as "A through K." The following provides the NDEP with information to determine if corrective action is required.

Depth of groundwater (A): Depth to groundwater at the site is estimated to be at $597 \mathrm{~m}$ $(1,960 \mathrm{ft})$ below ground surface. The estimated depth is based on the regional potentiometric surface map provided in the DOE Environmental Impact Statement (DOE, 1996).

The test that formed the U-2bu subsidence crater was detonated below the groundwater level. However, the collapse zone that formed below the crater is not considered a preferential pathway for transport of petroleum hydrocarbons to the groundwater. This determination is based on the extensive studies of the subsidence craters in the Area 3 Radioactive Waste Management Area, which is located in Yucca Flat approximately $8 \mathrm{~km}(5 \mathrm{mi})$ south of the U-2bu subsidence crater. In particular, the collapse zone of the U-3bh subsidence crater was studied by drilling from the crater floor directly into the collapse zone to a depth below natural ground surface of $150 \mathrm{~m}$ (492 ft). The collapse zone under U-3at, U-3ax and U-3bl were also studied by drilling angle holes under the craters and into the collapse zone. Samples were collected and analyzed for both physical and hydraulic properties (Schmeltzer et al., 1996; DOE1998b).

These studies concluded that the physical and hydraulic properties of the collapse zone below the crater are undifferentiated from those of the undisturbed alluvium ( Schmeltzer et al., 1996; DOE1998b). Comparison of the properties of the collapse zone and the undisturbed alluvium suggests that the collapse zone is neither more nor less homogeneous than the native alluvium. In addition, as part of the core descriptions, geologists described visual indications of moisture content, particle size distribution, lithology, sorting, grain shape, and any anomalies including indications of preferential pathways. No visual evidence of preferential pathways for water was observed in the cores.

Historical aerial photographs of the U-2bu subsidence crater from the late 1970's and early 1980's show varying degrees of ponding in the crater. Visual observations of the crater bottom indicate that is ringed by trees and large shrubs and contains mud desiccation cracks, which indicates that ponding has occurred and abnormal drainage pathways are not present under the crater. Photographs showing ponding and vegetation growth are included in Appendix C. According to the studies (Schmeltzer et al., 1996; DOE1998b), infiltration and ponding in the craters has lead to a zone of higher water content in the collapse zone of the craters than background. However, the depth of the zone varies depending on past precipitation events and the size of the catchment area for a particular crater. For the U-3bh crater, this zone extended to a depth of approximately $80 \mathrm{~m}$ $(263 \mathrm{ft})$. However, data from the characterization of $\mathrm{U}-3 \mathrm{bh}$ show effects of evaporation extending 
as deep as $45 \mathrm{~m}(148 \mathrm{ft})$. In addition, the vadose zone below $80 \mathrm{~m}(263 \mathrm{ft})$

at U-3bh showed no influence from the presence of the crater. Below this depth, conditions are the same as those for native alluvium.

Comparison of mean and standard deviations for physical and hydraulic properties of the collapse zone demonstrates that these properties have not been altered by the nuclear test. These results indicated that the collapse zone is not a preferential pathway and there is no indication of enhanced permeability.

Distance to irrigation or drinking water wells (B): The nearest water supply is located at Well 2, approximately $4.8 \mathrm{~km}$ (3 mi) north of the site. This well is inactive. The static water level

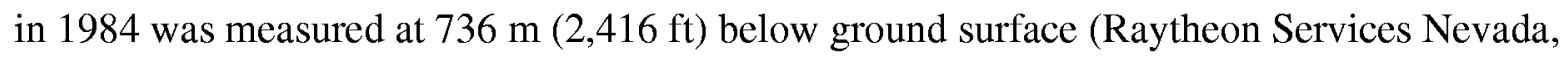
1986). The nearest active well is UE-16d, which is located approximately $16 \mathrm{~km}$ (10 mi) southwest of the site (DOE, 1996). The locations of all water wells at the NTS are shown in Figure A-1.

Type of soil (C): Geotechnical results from soils at the bottom of the U-2bu subsidence crater collected during the characterization of the site consisted of 91 percent silt and clay with 9 percent sand content (DOE, 1998a). These site characterization samples were not intended to characterize the collapse zone. However, they representative the material that was disposed in the crater and the finer material that has washed down with run-on. Given the similar geologic and hydrologic settings throughout Yucca Flat, the soils from the U-3bh collapse zone are considered similar to those of U-2bu. Soils from the U-3bh collapse zone were found to contain approximately 61 to 95 percent sand, with an average of 81 percent (DOE, 1998b). The silt and clay fractions were less than 30 and 10 percent respectively. These fractions are typical of a loamy sand to sandy loam texture, which is also typical of undisturbed alluvium in Yucca Flat. Whereas particle size fractions are similar to undisturbed samples, on average, the silt fraction in the collapse zone is 3 percent higher than the mean for the undisturbed samples. This increase is possibly due to sediment deposition in the bottom of the crater. Dry bulk densities ranged from 1,230 to 1,830 kilograms per cubic meter, with no obvious trend with depth. These values are within the range of bulk densities commonly observed for undisturbed alluvium on the NTS (DOE, $1998 \mathrm{~b}$ ). These values are also in the range of the soils collected from the gully and sides of the U-2bu subsidence crater (DOE, 1998a).

Annual precipitation (D): Annual rainfall in the site vicinity over a three-year period (February 1960 to August 1964) is tabulated in the report, Daily, Seasonal, and Annual Precipitation at the Nevada Test Site, Nevada, (Desert Research Institute [DRI], 1986). The data was collected from Station 353, which is located near the Area 2 Base Camp and had a recorded average annual precipitation of $10.9 \mathrm{~cm}$ (4.31 in) for the time period measured (DRI, 1986). Long-term 


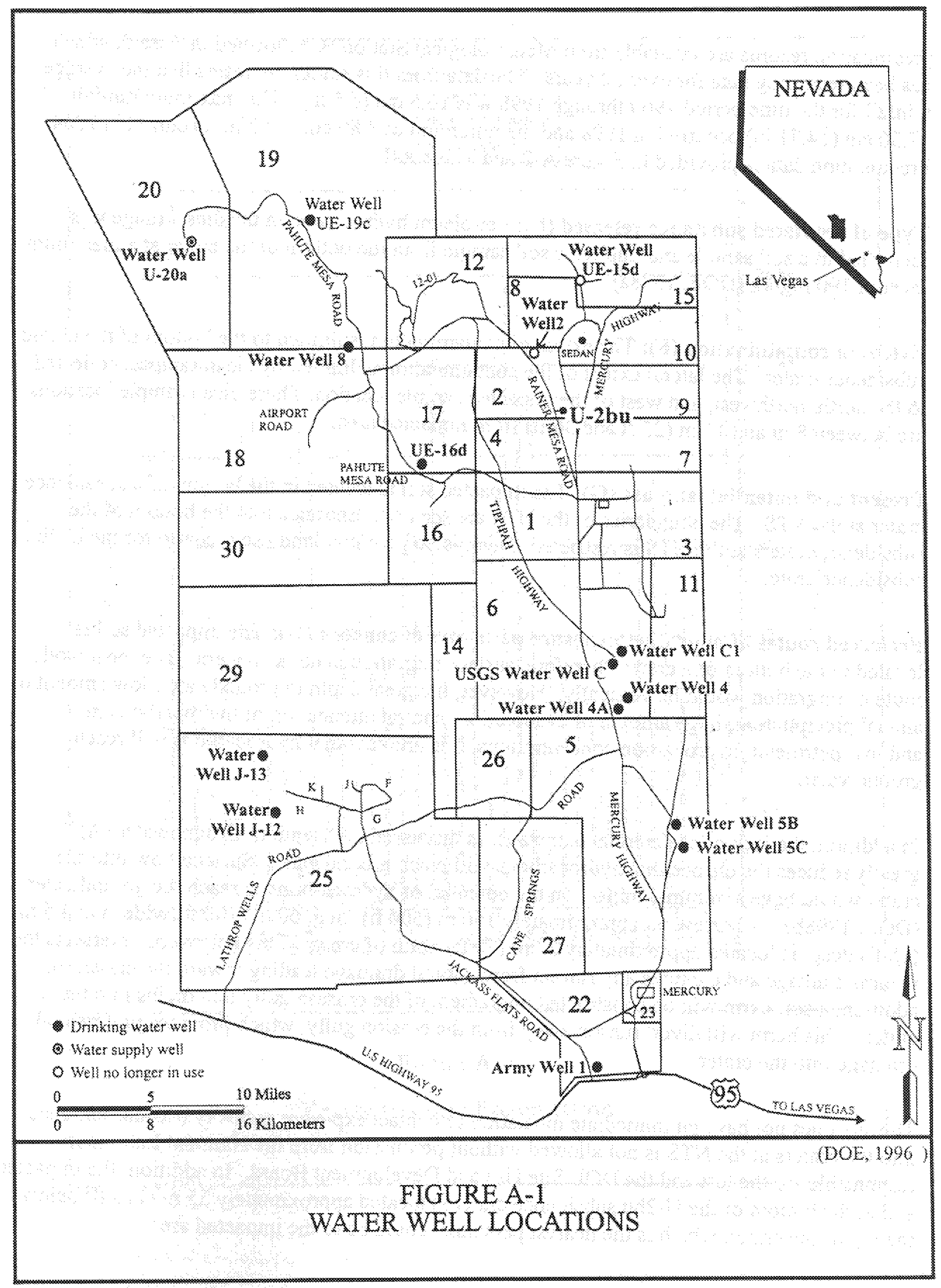


precipitation records are available from Meteorological Station BJY, located

in Area 3, which has been recording data for over 30 years. The data from this station indicates that the average rainfall for the time period 1960 through 1998 was $16.5 \mathrm{~cm}$ (6.5 in). The maximum rainfall of $37.36 \mathrm{~cm}$ (14.71 in) occurred in 1998 and the minimum of $3.89 \mathrm{~cm}(1.53 \mathrm{in})$ occurred in 1964. Precipitation data is provided in Figure A-2 and Table A-1.

Type of regulated substance released (E): Petroleum hydrocarbon in the diesel range was identified in a soil sample and duplicate soil sample from the bottom of the crater at a maximum level of $190 \mathrm{mg} / \mathrm{kg}$ (DOE, 1998a).

Extent of contamination (F): The extent of contamination is limited to the bottom of the U-2bu subsidence crater. The lateral extent of the contamination is limited by clean samples collected to the north, northwest, and west of the impacted sample location. These clean sample locations are

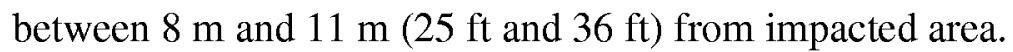

Present and potential land use (G): The impacted soil is located in the bottom of a subsidence crater at the NTS. The boundaries of the NTS are secured. Entrance into the bottom of the subsidence craters at the NTS is restricted. There is no potential land use scenario for the U- $2 \mathrm{bu}$ subsidence crater.

Preferred routes of migration/exposure pathways of concern $(\mathbf{H})$ : The impacted soil is located in the bottom of a crater, therefore, surface migration is not a concern. The most likely route of migration would be vertically. However, the great depth to groundwater, low amount of annual precipitation, large amount of evaporation, natural attenuation of hydrocarbons in soil, and low petroleum hydrocarbon concentrations, it is unlikely that hydrocarbons will reach groundwater.

In addition, the lack of preferential pathways, as discussed in "Depth to Groundwater (A)," greatly reduces the chance that hydrocarbons will reach groundwater. Surface flow into the crater would have a minimal impact on the potential of hydrocarbons to reach the groundwater (DOE, 1998b). A borrow pit approximately $150 \mathrm{~m}(500 \mathrm{ft})$ long, $60 \mathrm{~m}(200 \mathrm{ft})$ wide, and $4.5 \mathrm{~m}(15 \mathrm{ft})$ deep, is located approximately $20 \mathrm{~m}(70 \mathrm{ft})$ north of crater. This borrow pit intersects the natural drainage and captures any run-on from natural drainage leading toward the crater. In addition, a soil berm will be constructed upgradient of the erosion gully that drains into the crater. This berm will divert run-on away from the erosion gully, which provides preferential drainage into the crater.

The site does not have an immediate inhalation or contact exposure pathway because entrance into the craters at the NTS is not allowed without permission from the National Laboratory responsible for the test and the DOE Site Use and Development Board. In addition, the impacted soil at the bottom of the U-2bu subsidence crater is located approximately $35 \mathrm{~m}$ (115 ft) below the top of the crater, which is the nearest personnel could be to the impacted area. 


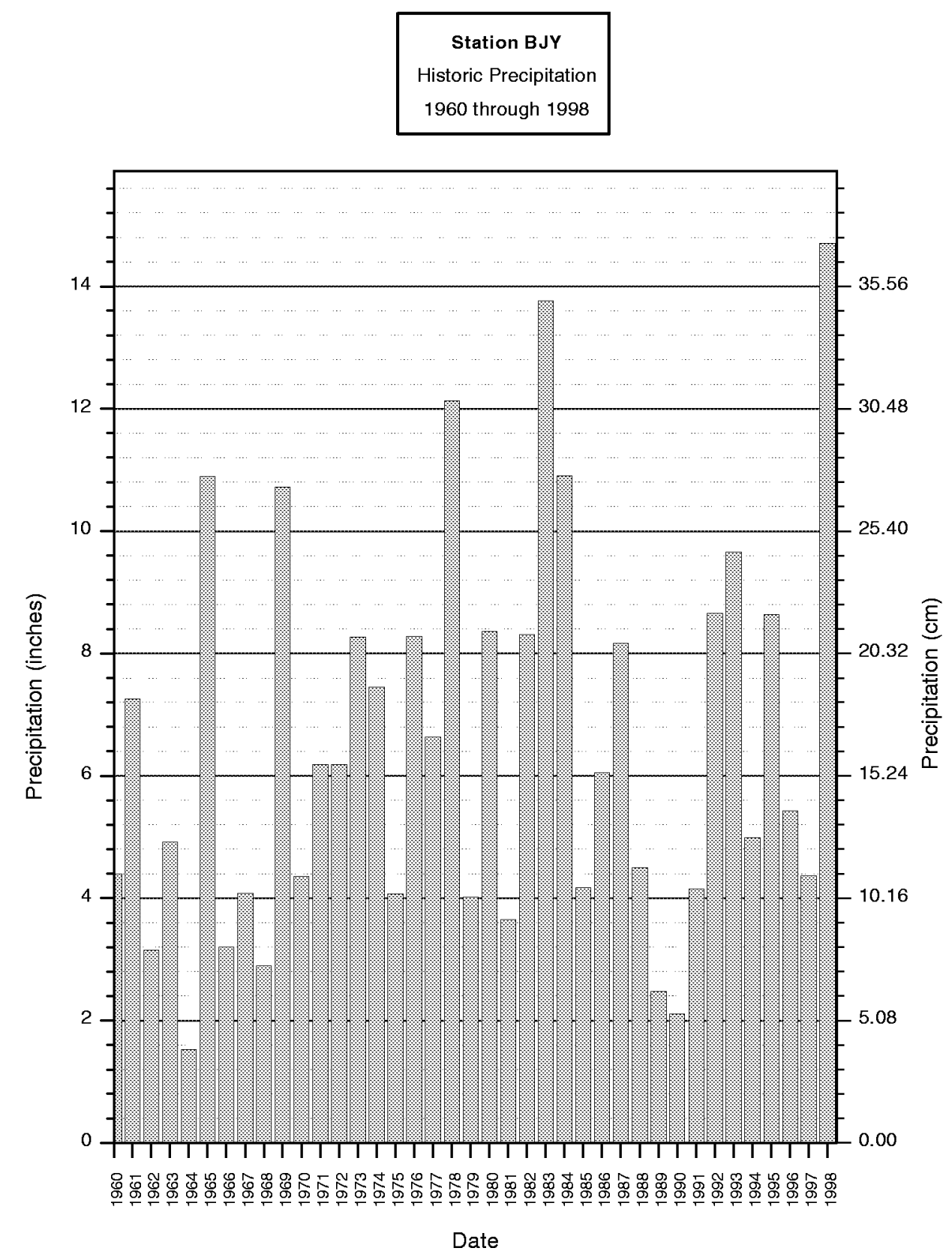

Figure A-2

Yearly Historic Precipitation 


\begin{tabular}{|c|c|c|c|c|c|c|c|c|c|c|c|c|c|}
\hline $\begin{array}{l}\text { BJY } \\
\text { PRECI } \\
\text { P }\end{array}$ & JAN & FEB & MAR & APR & MAY & JUN & JUL & AUG & SEP & OCT & NOV & DEC & $\begin{array}{l}\text { YEARLY } \\
\text { AVERAGE }\end{array}$ \\
\hline 1960 & $\begin{array}{l}\star \star \star \star \star \star \\
\star \\
*\end{array}$ & 0.15 & 0.28 & 0.18 & 0.02 & 0.42 & 0.02 & 0.01 & 0.97 & 0.87 & 1.48 & 0 & 4.40 \\
\hline 1961 & 0.38 & 0 & 0.53 & 0.38 & 0.29 & 0.02 & 0.94 & 2.64 & 0 & 0.17 & 0.86 & 1.05 & 7.26 \\
\hline 1962 & 0.11 & 1.22 & 0.18 & 0.02 & 0.08 & 0.11 & 0.45 & 0 & 0.52 & 0.16 & 0.01 & 0.29 & 3.15 \\
\hline 1963 & 0.04 & 0.46 & 0.38 & 0.15 & 0.46 & 0.64 & 0.01 & 0.43 & 1.89 & 0.12 & 0.32 & 0.02 & 4.92 \\
\hline 1964 & 0 & 0 & 0.06 & 0.2 & 0.17 & 0.09 & 0.64 & 0.18 & 0 & 0.04 & 0.15 & 0 & 1.53 \\
\hline 1965 & 0.27 & 0.03 & 0.49 & 2.4 & 0.25 & 0.14 & 1.54 & 0.82 & 0.02 & 0.11 & 2.37 & 2.45 & 10.89 \\
\hline 1966 & 0.16 & 0.09 & 0.01 & 0 & 0 & 0 & 0.94 & 0.62 & 0.21 & 0 & 0.01 & 1.16 & 3.20 \\
\hline 1967 & 0.51 & 0.22 & 0.06 & 0.63 & 0.23 & 0.12 & 0.68 & 0.25 & 0.41 & 0 & 0.58 & 0.39 & 4.08 \\
\hline 1968 & 0.01 & 1.16 & 0.16 & 0.15 & 0 & 0.25 & 0.66 & 0.24 & 0 & 0.15 & 0.11 & 0.01 & 2.90 \\
\hline 1969 & 3.41 & 3.17 & 0.55 & 0.19 & 0.07 & 0.78 & 0.72 & 0.03 & 1.21 & 0.24 & 0.33 & 0.02 & 10.72 \\
\hline 1970 & 0.08 & 0.8 & 0.41 & 0.28 & 0 & 0.09 & 0.09 & 1.2 & 0.02 & 0 & 1.29 & 0.09 & 4.35 \\
\hline 1971 & 0 & 0.33 & 0.02 & 0.41 & 1.69 & 0 & 0.39 & 0.67 & 0.05 & 0.01 & 0.01 & 2.61 & 6.19 \\
\hline 1972 & 0 & 0 & 0 & 0.01 & 0.08 & 1.22 & 0.02 & 0.69 & 0.82 & 1.49 & 1.85 & 0.01 & 6.19 \\
\hline 1973 & 1.11 & 2.06 & 3.58 & 0.21 & 0.2 & 0.14 & 0 & 0.05 & 0.01 & 0.37 & 0.32 & 0.22 & 8.27 \\
\hline 1974 & 2.29 & 0 & 0.66 & 0.03 & 0 & 0 & 1.1 & 0.4 & 0 & 1.36 & 0.04 & 1.57 & 7.45 \\
\hline 1975 & 0.05 & 0.1 & 1.36 & 0.61 & 0.82 & 0 & 0.08 & 0.05 & 0.21 & 0.75 & 0.02 & 0.02 & 4.07 \\
\hline 1976 & 0 & 3.1 & 0.23 & 0.47 & 0.38 & 0 & 0.74 & 0 & 1.6 & 1.41 & 0 & 0.35 & 8.28 \\
\hline 1977 & 1.06 & 0 & 0.04 & 0 & 2.02 & 0.41 & 0.07 & 2.38 & 0 & 0.07 & 0.1 & 0.48 & 6.63 \\
\hline 1978 & 2.44 & 3.42 & 2.83 & 0.49 & 0.05 & 0 & 0.48 & 0 & 0.68 & 0.3 & 0.88 & 0.56 & 12.13 \\
\hline 1979 & 1.08 & 0.44 & 0.98 & 0 & 0.08 & 0.01 & 0.76 & 0.4 & 0.02 & 0 & 0 & 0.25 & 4.02 \\
\hline 1980 & 2.6 & 1.75 & 1.92 & 0.4 & 0.23 & 0.15 & 0.77 & 0.13 & 0.37 & 0 & 0 & 0.04 & 8.36 \\
\hline 1981 & 0.32 & 0.06 & 1.46 & 0.42 & 0.15 & 0 & 0 & 0.1 & 0.46 & 0.23 & 0.45 & 0 & 3.65 \\
\hline 1982 & 0.61 & 0.16 & 2.22 & 0.42 & 0.61 & 0.08 & 0.44 & 1.08 & 1.02 & 0.1 & 1.22 & 0.35 & 8.31 \\
\hline 1983 & 1.72 & 0.58 & 2.75 & 0.48 & 0.36 & 0 & 0 & 4.93 & 0.99 & 0.06 & 0.71 & 1.18 & 13.76 \\
\hline 1984 & 0 & 0.1 & 0 & 0.02 & 0 & 0.75 & 3.42 & 3.04 & 0.03 & 0.21 & 0.9 & 2.43 & 10.90 \\
\hline 1985 & 0.88 & 0.15 & 0.21 & 0.01 & 0.19 & 0.36 & 0.84 & 0 & 0.09 & 0.21 & 1.09 & 0.14 & 4.17 \\
\hline 1986 & 1.28 & 0.51 & 1.1 & 0.16 & 0.1 & 0.02 & 0.55 & 0.33 & 0.02 & 0.46 & 0.59 & 0.93 & 6.05 \\
\hline 1987 & 1.25 & 0.3 & 0.37 & 0.64 & 1.56 & 0.27 & 1.41 & 0 & 0 & 0.87 & 0.86 & 0.64 & 8.17 \\
\hline 1988 & 1.3 & 0.27 & 0.02 & 1.31 & 0.29 & 0.13 & 0.06 & 0.73 & 0.01 & 0 & 0.15 & 0.23 & 4.50 \\
\hline 1989 & 0.27 & 0.48 & 0.02 & 0 & 0.96 & 0.15 & 0 & 0.55 & 0 & 0.05 & 0 & 0 & 2.48 \\
\hline 1990 & 0.52 & 0.13 & 0.22 & 0.2 & 0.12 & 0 & 0.36 & 0.29 & 0.15 & 0 & 0.07 & 0.05 & 2.11 \\
\hline 1991 & 0.12 & 0.76 & 1.08 & 0.01 & 0.19 & 0.1 & 0.06 & 0.31 & 0.34 & 0.26 & 0 & 0.92 & 4.15 \\
\hline 1992 & 0.42 & 1.53 & 1.86 & 0 & 1.36 & 0.2 & 0.41 & 0 & 0 & 0.81 & 0 & 2.07 & 8.66 \\
\hline 1993 & 3.44 & 3.36 & 0.7 & 0 & 0 & 0.36 & 0 & 0.41 & 0.04 & 0.39 & 0.49 & 0.47 & 9.66 \\
\hline 1994 & 0.36 & \begin{tabular}{|l|}
0.69 \\
\end{tabular} & 0.71 & \begin{tabular}{|l|}
0.26 \\
\end{tabular} & 0.39 & 0 & 0.15 & 0.13 & 0.08 & 0.02 & 0.57 & 1.63 & 4.99 \\
\hline 1995 & 3.09 & 1.25 & 2.55 & 0.56 & 0.71 & 0.16 & 0.13 & 0.16 & 0 & 0.03 & 0 & 0 & 8.64 \\
\hline 1996 & 0.11 & 0.38 & 0.21 & 0 & 0.26 & 0.33 & 0.36 & 0.05 & 0 & 0.67 & 2.48 & 0.58 & 5.43 \\
\hline 1997 & & 0.09 & 0 & 0 & 0.06 & 0.55 & 0.15 & 0.12 & 1.34 & 0 & 0.44 & 0.61 & 4.36 \\
\hline 1998 & 0.43 & 5.68 & 1.67 & 0.66 & 0.56 & 2.16 & 1.42 & 0.81 & 0.61 & 0.59 & 0.11 & 0.01 & 14.71 \\
\hline erage & 0.86 & 0.90 & 0.82 & 0.32 & 0.38 & 0.26 & 0.53 & 0.62 & 0.36 & 0.32 & 0.53 & .61 & 6.50 \\
\hline
\end{tabular}


Location of structures or impediments (I): There are no structures within

the immediate vicinity of the U-2bu subsidence crater. Other impediments include the remote location of the subsidence crater and the presence of impacted soil only in the bottom of the subsidence crater.

Potential for hazard related to fire, vapor, or explosion $(\mathbf{J})$ : The potential for fire, vapor ignition, or explosion at the site as a result of the release is extremely low. The impacted soil is below ground surface, at the bottom of the subsidence crater, and consists of weathered diesel. Field screening performed at the time of site characterization indicated that levels of volatile organic compounds are very low and do not exist in concentrations to support combustion.

Other factors specific to the site (K): The following are additional factors specific to the site that should be considered in the evaluation for closure:

C The U-2bu subsidence crater was closed to disposal in March 1989. Therefore, no additional petroleum hydrocarbons will be disposed in the crater and the concentrations will decrease over time due to natural degradation.

C The impacted soil is located in the bottom of the U-2bu subsidence crater and access is restricted into all craters on the NTS. In addition, boundaries of the NTS are secured. The likelihood that the site will be used for future private use is very low.

C Based on the results of the Characterization Report (DOE, 1998a), no other constituents of concern were identified above regulatory limits in the area impacted with petroleum hydrocarbons and the concentrations of diesel were very low $(190 \mathrm{mg} / \mathrm{kg})$.

C The presence of low levels of petroleum hydrocarbons within a crater created from the detonation of a nuclear device presents minimal concerns to the environment (i.e., soil and ground water) in contrast to the radioactive constituents still present in the subsurface as a result of the nuclear testing. 
DOE, see U.S. Department of Energy

DRI, see Desert Research Institute

Desert Research Institute, 1986, Daily. Seasonal, and Annual Precipitation at the Nevada Test Site, Nevada, Las Vegas, NV

NAC, see Nevada Administrative Code

Nevada Administrative Code, 1996a, NAC 445A, Corrective Action, Carson City, NV.

Schmeltzer, J.S., Barker, L.E., and Blout, D.O., 1996, Site Characterization Data from the

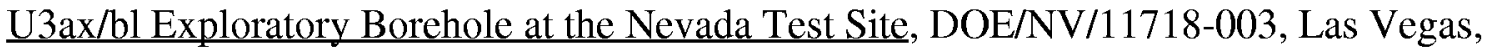
NV.

Raytheon Services Nevada, 1986, Nevada Site Development Plan, Part I, Las Vegas, NV

U.S. Department of Energy, Nevada Operations Office, 1996, Environmental Impact Statement for the Nevada Test Site and Off-Site Locations in the State of Nevada, DOE/EIS 0243, Las Vegas, NV.

U.S. Department of Energy, Nevada Operations Office, 1998a, Characterization Report for Corrective Action Unit 109: Area 2 U-2bu Crater, Nevada Test Site, Nevada, Revision 1, DOE/NV-517, Las Vegas, NV.

U.S. Department of Energy, Nevada Operations Office, 1998b, Hydrogeologic Characterization of the Unsaturated Zone at the Area 3 Radioactive Waste Management Site, DOE/NV/11718-210, Las Vegas, NV. 


\section{APPENDIX B}

\section{CONTINGENCY PLAN}




\section{AREA 2 \\ U-2BU SUBSIDENCE CRATER CONTINGENCY PLAN AND EMERGENCY PROCEDURES}

March 1999

Prepared for U. S. Department of Energy Nevada Operations Office Environmental Restoration Division 


\section{THIS PAGE INTENTIONALLY LEFT BLANK}




\section{APPROVALS}

Approved By:

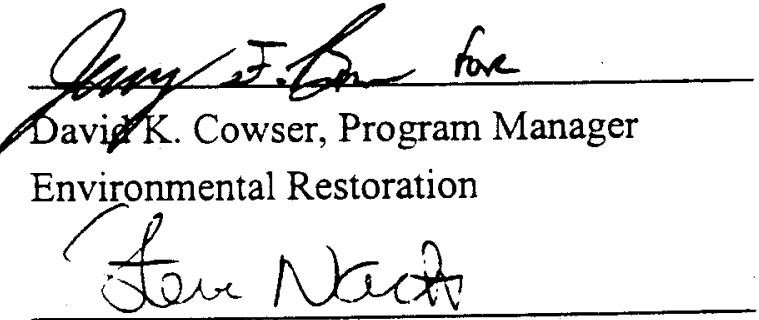

Steve J. Nacht, Project Manager

Environmental Restoration

Concurred By:

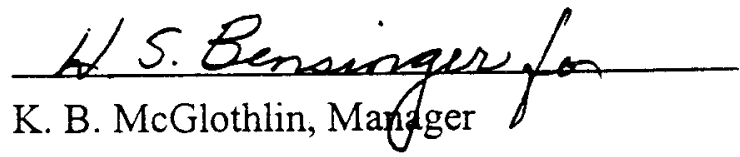

Emergency Services

$$
\text { Jery } 7 \text {. Bonn, Task Manager }
$$

Environmental Restoration

Prepared By:

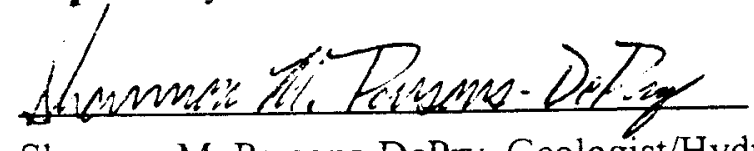

Shannon M. Parsons-DePry, Geologist/Hydrogeologist

Environmental Restoration
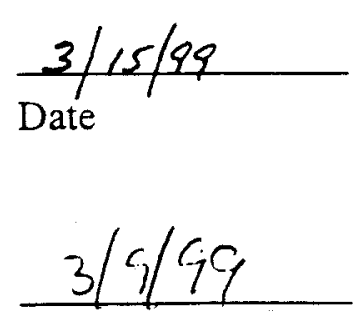

Date

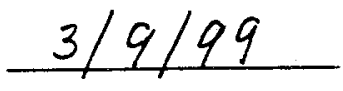

Date
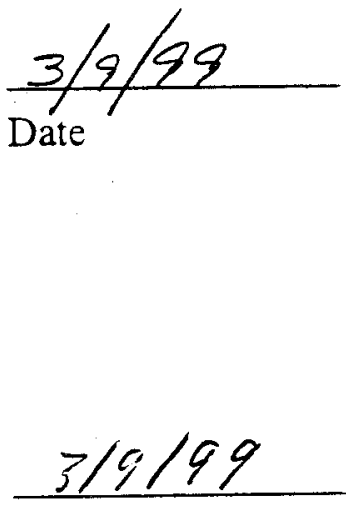

Date 
THIS PAGE INTENTIONALLY LEFT BLANK 


\section{TABLE OF CONTENTS}

FIGURES $\ldots \ldots \ldots \ldots \ldots \ldots \ldots \ldots \ldots \ldots \ldots \ldots \ldots \ldots \ldots \ldots \ldots \ldots \ldots \ldots \ldots$

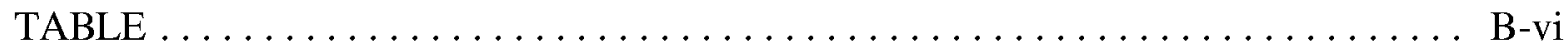

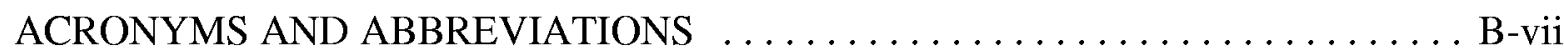

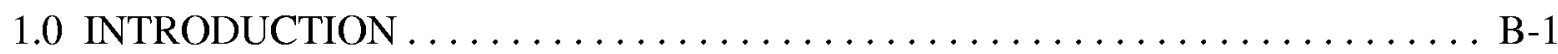

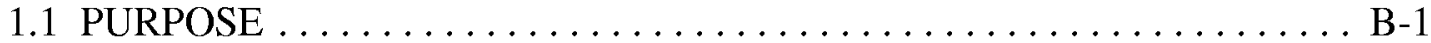

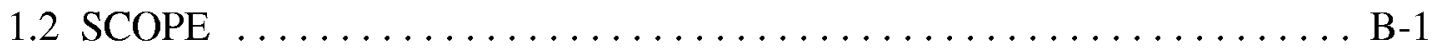

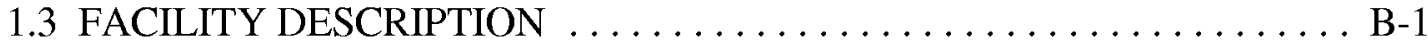

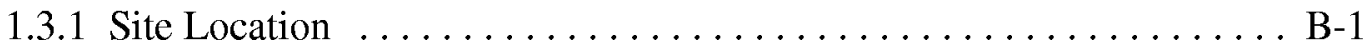

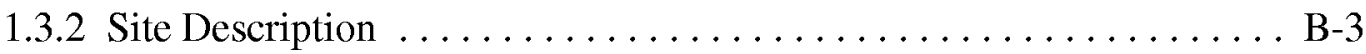

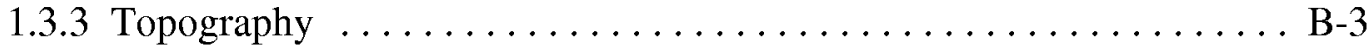

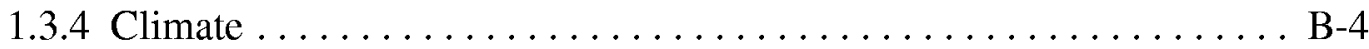

2.0 WASTE DESCRIPTIONS AND ASSOCIATED HAZARDS $\ldots \ldots \ldots \ldots \ldots$ B-5

2.1 CHEMICAL HAZARDS $\ldots \ldots \ldots \ldots \ldots \ldots \ldots \ldots \ldots \ldots \ldots \ldots \ldots . \ldots \ldots$

2.1.1 RCRA-Regulated Constituents $\ldots \ldots \ldots \ldots \ldots \ldots \ldots \ldots \ldots \ldots$ B-5

2.1.2 Radiological Constituents $\ldots \ldots \ldots \ldots \ldots \ldots \ldots \ldots \ldots \ldots \ldots . \ldots \ldots$ B -5

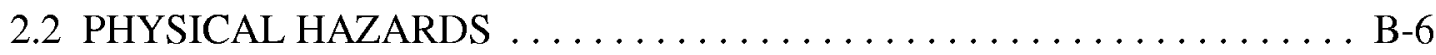

2.2.1 RCRA-Regulated Constituents $\ldots \ldots \ldots \ldots \ldots \ldots \ldots \ldots \ldots$ B-6

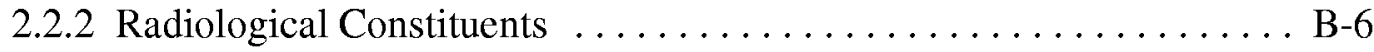

2.2 .3 Other Physical Hazards $\ldots \ldots \ldots \ldots \ldots \ldots \ldots \ldots \ldots \ldots \ldots \ldots . \ldots \ldots$

3.0 EMERGENCY NOTIFICATION PROCEDURES $\ldots \ldots \ldots \ldots \ldots \ldots \ldots \ldots$ B-7

3.1 DESIGNATION OF EMERGENCY COORDINATOR $\ldots \ldots \ldots \ldots \ldots$ B-7

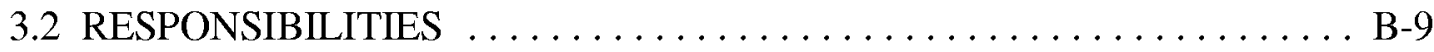

3.3 NOTIFICATION . . . . . . . . . . . . . . . . . . . . . . . B -10

3.4 RESPONSE PROCEDURES $\ldots \ldots \ldots \ldots \ldots \ldots \ldots \ldots \ldots \ldots \ldots \ldots \ldots \ldots \ldots$

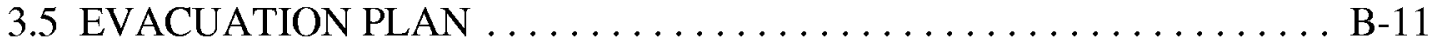

3.6 EMERGENCY DECONTAMINATION AND FIRST AID $\ldots \ldots \ldots \ldots$ B-11

3.7 CLEAN-UP ..................................... B-13

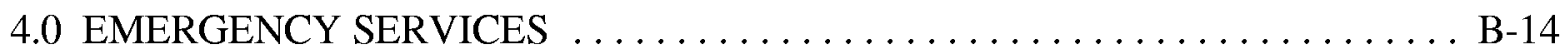

4.1 ON-SITE CONDITION OF EMERGENCY SERVICES $\ldots \ldots \ldots \ldots . . .14$

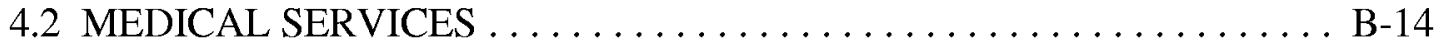

4.3 FIRE PROTECTION AND EMERGENCY MEDICAL SERVICES .... . B-14 


\section{TABLE OF CONTENTS (Continued)}

5.0 EMERGENCY EQUIPMENT $\ldots \ldots \ldots \ldots \ldots \ldots \ldots \ldots \ldots \ldots \ldots \ldots$. . . . . . . . . . .

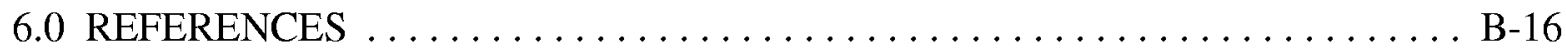

\section{FIGURES}

Figure 1 - Location of $\mathrm{U}-2 \mathrm{bu}$ Subsidence Crater . . . . . . . . . . . . . . . . B-2

Figure 2 - Emergency/Contingency Plan Notice $\ldots \ldots \ldots \ldots \ldots \ldots \ldots \ldots \ldots$

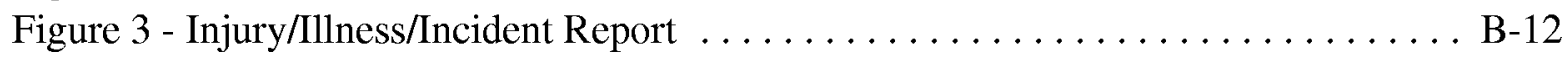

\section{TABLE}

Table 1 - List of Available Equipment and Location . . . . . . . . . . . . . . B-15 


\section{ACRONYMS AND ABBREVIATIONS}

$\mathrm{BN}$

CFR

DOE

$\mathrm{EC}$

EMP

ER

$\mathrm{mg} / \mathrm{L}$

NTS

PPE

RCRA
Bechtel Nevada

Code of Federal Regulations

U.S. Department of Energy

Emergency Coordinator

Emergency Management Plan

Environmental Restoration

milligrams per liter

Nevada Test Site

Personal Protective Equipment

Resource Conservation and Recovery Act 
THIS PAGE INTENTIONALLY LEFT BLANK

B-viii 


\subsection{INTRODUCTION}

\subsection{PURPOSE}

This document satisfies the requirements for a contingency plan and emergency procedures required by the federal hazardous waste regulations defined in the Resource Conservation and Recovery Act (RCRA). These requirements are prescribed by:

- Title 40 Code of Federal Regulations (CFR) Part 265, Subparts C and D (EPA, 1996a)

- $\quad$ Title 40 CFR 262.34 (EPA, 1996b)

- $\quad$ Title 29 CFR 1910.120, "Hazardous Waste Operations and Emergency Response" (EPA, 1996c)

- $\quad$ Bechtel Nevada (BN) Emergency Management Plan (EMP) (BN, 1998)

This plan discusses the actions that the BN Environmental Restoration (ER) and other Nevada Test Site (NTS) personnel will take in response to fires, explosions, or unplanned sudden or non-sudden releases of hazardous waste or hazardous waste constituents to the air, soil, or surface water at the U-2bu subsidence crater during closure activities.

\subsection{SCOPE}

This Plan covers a variety of emergencies at the U-2bu subsidence crater. This document applies to all personnel assigned to the U-2bu subsidence crater project activities.

\subsection{FACILITY DESCRIPTION}

\subsubsection{Site Location}

The U-2bu subsidence crater is an historic land disposal unit located in Area 2 of the NTS (Figure 1). It was created in 1971 by an underground nuclear test with the name Miniata. 



\subsubsection{Site Description}

The subsidence crater was used as a land disposal unit for radioactive and hazardous waste from 1973 to 1988 . The site disposal history is supported by memorandums, letters, and personnel who worked at the NTS at the time of active disposal. Wastes included radioactive drilling mud that also contained chromium and possibly lead. Drilling mud was collected in a vacuum truck, transported to U-2bu and dumped into the crater from the northern rim. The vacuum trucks were rinsed with water, which was also disposed in the crater. Nevada Test Site personnel report that drilling mud from the Baneberry test cleanup and the Area 9 Integrated Test Series, including the Avens-Cream test, were disposed in U-2bu. The total volume of drilling mud and associated rinsate disposed at $\mathrm{U}-2 \mathrm{bu}$ is unknown.

In addition to the drilling mud, 13,250 to 18,925 liters (3,500 to 5,000 gallons) of wastewater and sludge from the Area 6 Decontamination Facility sumps was disposed in U-2bu in November 1988. The wastewater contained solvents and mixed fission products. This was the last disposal of waste into U-2bu. Previous disposal of mixed hazardous and radioactive waste from the Decontamination Facility into the crater is undocumented, although personnel working at the facility at the time have stated that previous disposal activities of waste from the Decontamination Facility did take place in U-2bu. The volumes of waste disposed are unknown, however, the waste stream was likely similar to the wastewater and sludge disposed in November 1988 . Waste disposal into the crater was officially discontinued in March 1989.

Disposal of waste into the crater has resulted in the development of an erosion gully on the northeast side of the crater running from the top of the crater to an artificial alluvial fan that has formed at the bottom. Historical aerial photographs of the U-2bu subsidence crater show that the fan has grown over the years in association with the disposal of waste. The areal extent of the fan is currently 800 square meters (8,600 square feet) (Department of Energy [DOE], 1998).

\subsubsection{Topography}

The NTS is located in the Great Basin of the Basin and Range province. The U-2bu subsidence crater is located in Area 2 of the NTS. The topography and soils in Area 2 are typical of the NTS alluvial basins. The soil is dense, silty sand, which contains gravel and scattered boulders and common layers of caliche. Area 2 is located in Yucca Flat, which is a topographically closed basin that drains into Yucca Lake, a playa at the lowest portion of the basin. The topography of Area 2 has been greatly altered by the numerous underground nuclear detonation that took place in Yucca Flat. 


\subsubsection{Climate}

Lower elevations of the NTS receive approximately 15 centimeters (6 inches) of precipitation annually. Annual wind patterns are characterized by strong winds in the spring. The daily cycle is generally light winds at night, increasing winds from morning to afternoon and declining wind speed in the evening. Average monthly wind speed vary from 4 meters per second ( 13 feet per second) in April to 2.7 meters per second ( 9 feet per second) in November (Desert Research Institute, 1986). The temperatures at the NTS varies from average highs over $40^{\circ} \mathrm{C}\left(100^{\circ} \mathrm{F}\right)$ in the summer and average lows in the $0^{\circ} \mathrm{C}\left(30^{\circ} \mathrm{F}\right)$ in the winter. 


\subsection{WASTE DESCRIPTIONS AND ASSOCIATED HAZARDS}

The U-2bu subsidence crater contains materials that present chemical and physical hazards. Potential routes of entry could include inhalation, ingestion, absorption, and injection. The specific hazards associated with the site are described in the following sections.

\subsection{CHEMICAL HAZARDS}

The following is a generalization of the hazards associated with the various chemical classes that may possibly be encountered at the U-2bu subsidence crater. Although analytical data indicates the presence of these chemical classes in the soil, it should be noted that they were detected in small concentrations, as discussed below.

\subsubsection{RCRA-Regulated Constituents}

It is possible that RCRA-regulated hazardous constituents may be found at the site. Leachable lead was detected at a maximum concentration of 5.7 milligrams per liter $(\mathrm{mg} / \mathrm{L})$, in the soil samples collected during site characterization (DOE, 1998). This concentration exceeds the regulatory action level of $5.0 \mathrm{mg} / \mathrm{L}$. Although from a human health consideration, the levels are relatively low. Lead may be harmful or fatal if inhaled, ingested, or absorbed through the skin. Contact can cause abdominal pain and spasms, nausea, vomiting, headaches. Acute poisoning can lead to muscle weakness, "lead line" on gums, metallic taste, loss of appetite, insomnia, dizziness and shock, coma, and death in extreme cases. Target organs include the gum tissue, central nervous system, kidneys, blood, and reproductive systems.

\subsubsection{Radiological Constituents}

The main ionizing radiological constituents of concern are alpha particles. Alpha particles do not present an external hazard because they are easily stopped by the dead layer of skin on the body. However, alpha particles do present an internal hazard if inhaled or injected, and less of a hazard if ingested. Once inside the body, they tend to concentrate in the lungs, liver, and bones where they are in close contact with body tissue and can deposit large amounts of energy in a small volume of body tissue. 


\subsection{PHYSICAL HAZARDS}

The following is a generalization of the physical hazards associated with the various chemical classes that may possibly be encountered at the U-2bu subsidence crater.

\subsubsection{RCRA-Regulated Constituents}

The RCRA-regulated constituents themselves do not present any kind of physical hazard. All physical hazards will be associated with the removal and containerizing of the waste soil.

\subsubsection{Radiological Constituents}

The radiological constituents themselves do not present any kind of physical hazard. All physical hazards will be associated with the removal and containerizing of the waste soil.

\subsubsection{Other Physical Hazards}

Other physical hazards present at the U-2bu subsidence crater associated with container-handling, heavy equipment operations, working on a sloped embankment, and working outdoors. These may include potential back injury, vehicle accidents, slip, trip, and fall accidents, heat and cold stress. Physical hazards are discussed in BN safety procedures and the Site-Specific Health and Safety Plan. 


\subsection{EMERGENCY NOTIFICATION PROCEDURES}

The reporting and notification procedure outlined in BN Safety Procedure M-A11-007, Accidents/Incident Notifying. Investigating, and Reporting will be followed in the event of an accident, injury or other incident. Expedient reporting and notification will be made for, but not limited to, personnel injury or fatality, toxic material release, fire, or explosion. Figure 2 shows the Emergency/Contingency Plan notice that will be posted at the site. Information includes a list of the telephone numbers, emergency response procedures, waste description, etc.

\subsection{DESIGNATION OF EMERGENCY COORDINATOR}

The Emergency Coordinator (EC) system consists of one primary EC, one secondary EC, and one alternate EC. The ECs are onsite or on call at all times. In the event of an emergency, the primary EC should be contacted; if not available, the secondary EC should be contacted. If neither of these are available, the alternate should be contacted. The individual who is available first becomes the EC for the situation. Actual home addresses and phone numbers for ECs will be provided in the document used in the field. The ECs appointed by the Environmental Restoration Program Manager are as follows:

\section{Primary Emergency Coordinator}

Steve J. Nacht

Address: To be provided in field document
Work: (702) 295-7234

Pager: (702) 794-5692

Home: To be provided in field document

Net $3 \# 762$

\section{$\underline{\text { Secondary Emergency Coordinator }}$}

Jerry F. Bonn

Address: To be provided in field document
Work: (702) 295-7341

Pager: (702) 794-6325

Home: To be provided in field document

Net $3 \# 763$; Net 15 \#813 


\section{EMERGENCY/CONTINGENCY PLAN}

COMPANY: Bechtel Nevada

ADDRESS: Mercury, Nevada

LOCATION OF FACILITY: Nevada Test Site, Area 2

\section{PRIMARY EMERGENCY COORDINATOR}

Steve J. Nacht

Address: To be provided in field document
Work: (702) 295-7234

Pager: (702) 794-5692

Home: To be provided in field document

Net 3 \#762

\section{SECONDARY EMERGENCY COORDINATOR}

Jerry F. Bonn

Address: To be provided in field document
Work: (702) 295-7341

Pager: (702) 794-6325

Home: To be provided in field document

Net $3 \# 763$; Net $15 \# 813$

\section{ALTERNATE EMERGENCY COORDINATOR}

Shannon Parsons-DePry

Address: To be provided in field document
Work: (702) 295- 0645

Pager: (702) 794-5848

Home: To be provided in field document

Net $15 \# 824$

\section{DESCRIPTION OF WASTE HANDLED}

Possible radioactive constituents and metals contained in soil and decontamination water. Wastes are contained in B-25 boxes.

EMERGENCY RESPONSE CONTACTS

All emergency response teams can be contacted through the 900 Net Coordinator: "MAYDAY, MAYDAY, MAYDAY" OR "911"

\section{PRIMARY HOSPITAL:}

Area 6 295-3490

EMERGENCY MANAGEMENT OFFICE:

Area 23 295-1962

EMERGENCY CONTACT CENTER (24 hour contact numbers): 295-1381
SECONDARY HOSPITAL: Area 23 295-1702

FIGURE 2

EMERGENCY/CONTINGENCY PLAN NOTICE 


\section{Alternate Emergency Coordinator}

\author{
Shannon Parsons-DePry \\ Address: To be provided in field document
}

Work: (702) 295-0645

Pager: (702) 794-5848

Home: to be provided in field document

Net 15: \#824

\subsection{RESPONSIBILITIES}

The ECs have the authority to commit the necessary resources to implement this plan. Personnel resources will be applied consistent with the requirements of Title 29, CFR $\S 1910.120$ (EPA, 1996c). The ECs will remain thoroughly familiar with the following:

- All aspects of this Plan.

- All operations and activities under control at the U-2bu subsidence crater.

- The locations and characteristics of the wastes handled.

- The locations of all the records.

- $\quad$ The U-2bu subsidence crater layout.

In the event of an emergency, the EC will be responsible for the following:

- $\quad$ Stopping all operations, where applicable.

- Implementing this Plan.

- Contacting the 900 Radio Net Coordinator through the MAYDAY/911 system and making notification of the emergency.

- $\quad$ Notifying all pertinent personnel of the emergency.

- $\quad$ Acting as the incident coordinator.

- $\quad$ Attempting to stop, slow, or dike the discharge, if it can be done safely with the materials at hand. 
- $\quad$ Providing the technical expertise necessary so that all responders are fully informed of the potential hazards.

The secondary EC will also be responsible for preparing, posting, and maintaining an emergency information sheet that provides the emergency response information such as telephone number for emergency response teams. The secondary EC is also responsible for personnel evacuation. In the event the secondary EC is not available the alternate EC will conduct these duties.

\subsection{NOTIFICATION}

The first person who becomes aware of an emergency at the U-2bu subsidence crater shall immediately notify the proper authorities. Initial notification should be to their supervisor. If the emergency involves only a release of hazardous materials, the supervisor shall contact the EC who will initiate the necessary notification.

When the nature of the emergency is a fire, explosion, or involves personnel injury, the supervisor shall immediately notify the 900 Net Coordinator via the MAYDAY/911 system. The 900 Net Coordinator shall notify the Fire Protection Services Section and/or medical personnel, as required. The supervisor shall contact the EC.

If the first person to become aware of an emergency is not an ER employee and there are no ER personnel in the area, that person should follow the notification instructions posted at the designated field office.

\subsection{RESPONSE PROCEDURES}

There are two general classifications of incidents that could occur at the U-2bu subsidence crater; fire and/or explosions and a spill of potentially hazardous materials. The initial response will be to protect human health and safety, and then the environment. The following actions will be taken:

C Work in the area will cease immediately. 
C For fire: $\quad$ Contact the NTS Fire Protection and Emergency Medical Services by using the Net MAYDAY/911 system. In the case of a small, controllable fire, an ABC-type fire extinguisher can be used. If fire extinguisher is used, still contact NTS Fire Protection and Emergency Medical Services for follow-up requirements.

For spill: $\quad$ Attempt to stop, slow, or dike the discharge without compromising health and safety.

C Notify the EC who will obtain additional emergency response assistance as required. Evacuate area. Verify that all personnel are out of area.

C Remove injured persons and administer first aid as required.

C Shut down operating equipment as practical.

C Complete appropriate documentation (Figure 3).

\subsection{EVACUATION PLAN}

Notification for personnel to evacuate the area will be received by an emergency signal. The EC will be in possession of a blow-horn or similar device that will signal all workers to leave the area and gather in the designated assembly area. Evacuation notification will be discussed in the tailgate safety briefings. All radio nets will be kept clear and be used to transmit emergency information only. The EC will be accountable for all personnel. The assembly area for evacuated personnel will be at the field office. If cover must be taken, personnel will be instructed to enter the field trailer or field vehicles.

\subsection{EMERGENCY DECONTAMINATION AND FIRST AID}

If a worker is contaminated with a chemical substance, direct the worker to proceed at once to the temporary decontamination pad and drench the worker with copious amounts of water. Pay particular attention to the victim's eyes and face. Do not remove Personal Protective Equipment (PPE) until all contamination has been thoroughly rinsed off. Contact the Occupational Medicine Department for assistance and advice. Move the victim to fresh air. 


\section{Bechtel Nevada}

The supervisor completes this report immediately attor baing notified of any work-ralated accident or incident (injury, lliness, whicle sccident, proporty damage, or near-mias incident) and forwerds in to the assigned Sefety Papresentative or the Occupetional Sefety Department within two working days. Be specific Provide enough data that anyone reading the report, who is not tamillar with the incident, can understand what happened. For near-miss incidents complete Parts I and IV. For cocidents, injuries, or illnesses, complete the applicable blocks in Pars L II, III and N. (Instructions are libted on the beck of the lest copy.)

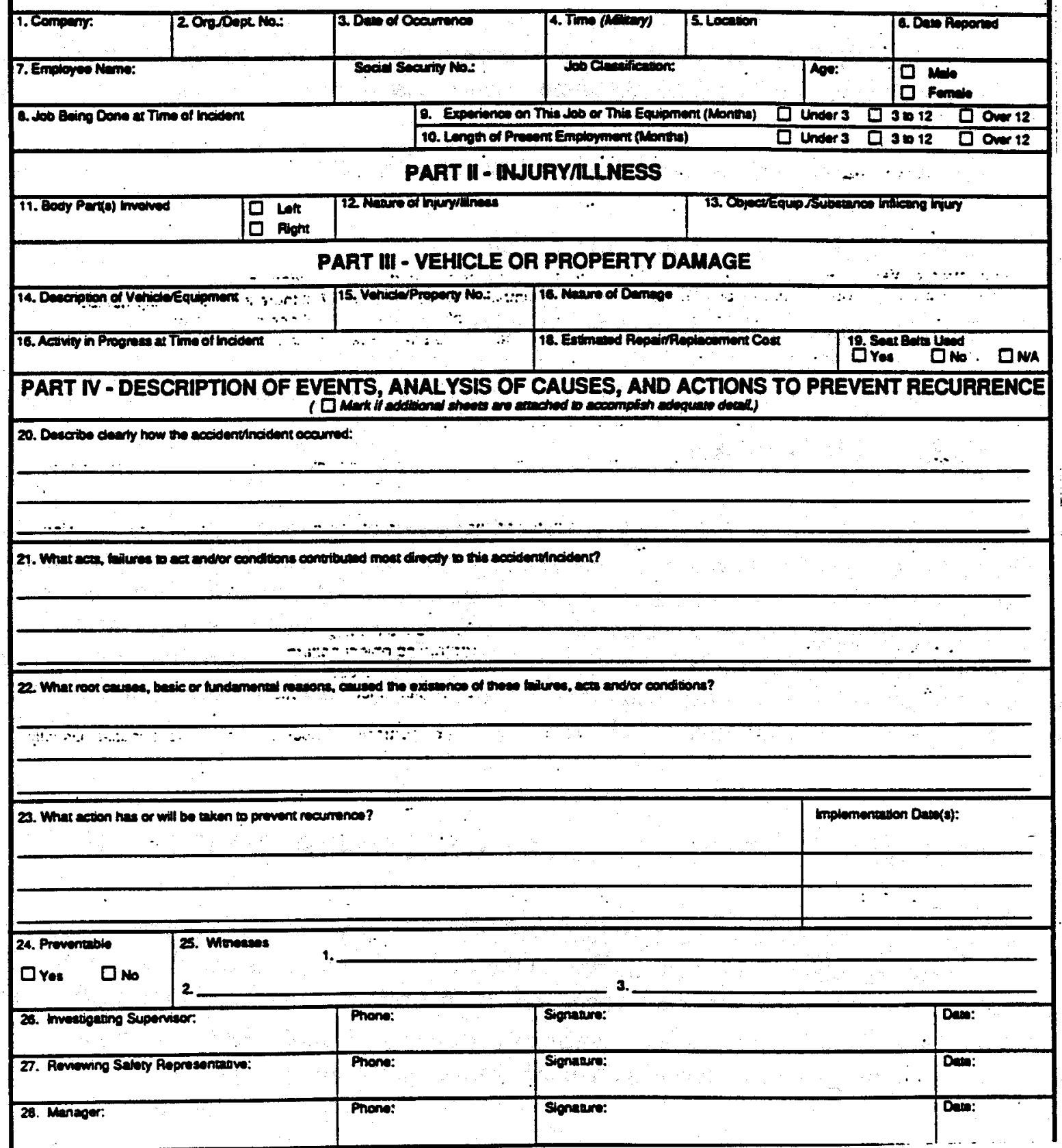




\subsection{CLEAN-UP}

Clean-up of potential hazardous waste will be conducted by personnel having the appropriate training and PPE as determined by the EC. Clean-up will meet all current applicable standards and regulations. 


\subsection{EMERGENCY SERVICES}

\subsection{ON-SITE CONDITION OF EMERGENCY SERVICES}

No coordination agreement with off-site organizations has been made because services are available onsite to respond to all credible emergencies. These services include the NTS Fire Protection and Emergency Medical Services, medical services, laboratory services, and radiological services and Industrial Hygiene services. These services are linked to the communications systems and have the capability to respond to emergencies involving hazardous, radioactive, or mixed waste constituents.

\subsection{MEDICAL SERVICES}

Emergency services are provided in Mercury 24 hours a day, seven days a week, by physicians, registered nurses, and/or paramedical personnel. Emergency services are also provided in Area 6 during normal working hours by paramedical personnel. All nurses and physicians are licensed by the state of Nevada paramedical qualifications, which meet or exceed U. S. Department of Transportation Highway Safety Program requirements for emergency medical services.

\subsection{FIRE PROTECTION AND EMERGENCY MEDICAL SERVICES}

The NTS Fire Station located in Mercury serves the NTS 24 hours a day, seven days a week. The NTS Fire Station located in Area 6 serves the NTS during normal working hours. It is located approximately 22 kilometers ( 14 miles) from the work site and will be the primary response team. The NTS Fire Protection and Emergency Medical Services responds to spills, explosions, fires, and non-fire emergencies involving cleanup. 


\subsection{EMERGENCY EQUIPMENT}

Emergency equipment includes equipment for fire control, emergency communications, spill control and cleanup, personnel protection, and first aid. The on-site emergency equipment is inspected monthly to ensure there is adequate inventory and that it is in good working order. Extra PPE, respiratory equipment, and environmental monitoring equipment are available. A list of the available equipment and the location(s) can be found in Table 1.

TABLE 1- LIST OF AVAILABLE EQUIPMENT AND LOCATION.

\begin{tabular}{|c|c|c|}
\hline \multicolumn{2}{|c|}{ EQUIPMENT } & LOCATION \\
\hline \multicolumn{2}{|c|}{ Fire Extinguishers (20 lb. ABC) } & Each Vehicle, Office \\
\hline \multicolumn{2}{|l|}{ First Aid Kits } & Each Vehicle, Office \\
\hline \multicolumn{2}{|c|}{ Eye Wash Station } & Hotline \\
\hline $\begin{array}{l}\text { PPE: } \\
\text { Tyvek } \\
\text { Nitrile Gloves } \\
\text { Rubber Boots } \\
\text { Rain Suits }\end{array}$ & $\begin{array}{l}\text { Emergency Respirators } \\
\text { Face Shield } \\
\text { Safety Glasses }\end{array}$ & Office or Designated Field Vehicle \\
\hline \multicolumn{2}{|c|}{ Portable Net 15 Radios with charger } & Office and Site Supervisor Vehicle \\
\hline \multicolumn{2}{|c|}{$\begin{array}{l}\text { Spill Response Materials: } \\
\text { Horn } \\
55 \text {-gallon drums } \\
\text { Spill Kit } \\
\text { Absorbent Pads }\end{array}$} & Office or Designated Field Vehicle \\
\hline $\begin{array}{l}\text { Miscellaneous: } \\
\text { Garbage Bags } \\
\text { Buckets } \\
\text { Brushes } \\
\text { Soap }\end{array}$ & $\begin{array}{l}\text { Kimwipes } \\
\text { Plastic } \\
\text { Sandbags } \\
\text { Duct Tape } \\
\end{array}$ & Office or Designated Field Vehicle \\
\hline
\end{tabular}




\subsection{REFERENCES}

Bechtel Nevada, 1996, Accident/Incident Notifying, Investigating, and Reporting, M-A11-007, Las Vegas, Nevada.

Becthel Nevada, 1998, Bechtel_Nevada Emergency Management Plan, Revision 0, B-2120/98.01, Las Vegas, NV.

Desert Research Institute, 1986, Daily. Seasonal, and Annual Precipitation at the Nevada Test Site, Nevada, Las Vegas, NV

U.S. Department of Energy, Nevada Operations Office, 1998, Characterization Report for Corrective Action Unit 109: Area 2 U-2bu Crater, Nevada Test Site, Nevada, Revision 1, DOE/NV--517, Las Vegas, NV.

U.S. Environmental Protection Agency, 1996a, 40 Code of Federal Regulations 265, Interim Status Standards for Owners and Operators of Hazardous Waste Treatment. Storage. and Disposal Facilities, Washington, DC.

U.S. Environmental Protection Agency, 1996b, 40 Code of Federal Regulations 262.34, Accumulation Time, Washington, DC.

U.S. Environmental Protection Agency, 1996c, 29 Code of Federal Regulations 1910.120, Hazardous Waste Operations and Emergency Response, Washington, DC. 
APPENDIX C

\section{PHOTOGRAPHS OF U-2BU SUBSIDENCE CRATER}




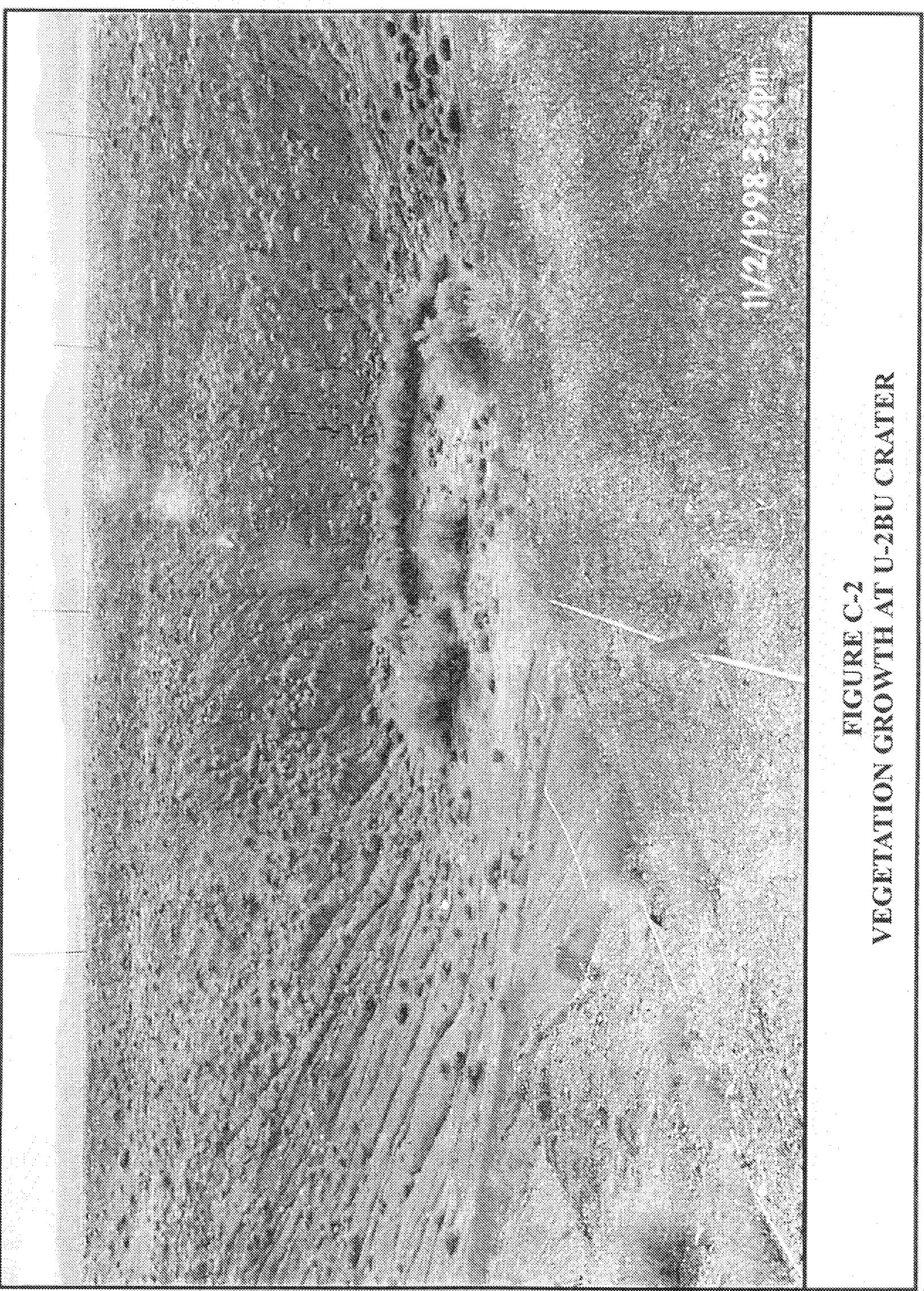




\section{APPENDIX D}

\section{PROJECT ORGANIZATION}


The following are the DOE/NV project contacts:

Runore C. Wycoff

Division Director

Environmental Restoration Division

U.S. Department of Energy, Nevada Operations Office

P.O. Box 98518

Las Vegas, NV 89193-8518

(702) 295-0250

Janet L. Appenzeller-Wing

Project Manager

Industrial Sites Project

U.S. Department of Energy, Nevada Operations Office

P.O. Box 98518

Las Vegas, NV 89193-8518

(702) 295-0461

The identification of the project Health and Safety Officer and the Quality Assurance Officer can be found in the appropriate DOE plan. However, personnel are subject to change and it is suggested that the Project Manager be contacted for further information. The Task Manager will be identified in the Federal Facility Agreement and Consent Order Biweekly Activity Report prior to the start of field activities. 


\section{DISTRIBUTION LIST}




\section{DISTRIBUTION LIST}

*Provide copy of initial distribution of Revision 0; remainder of list gets Revision 0 if approved without changes. The entire list receives Revision 1, if issued.

\section{Nevada Department of Environmental Protection}

Paul Liebendorfer

Bureau of Federal Facilities

Division of Environmental Protection

333 W. Nye Lane, Room 13B

Carson City, NV 89706-0866

Mike McKinnon, Las Vegas Office

Bureau of Federal Facilities

Division of Environmental Protection

555 E. Washington, Suite 4300

Las Vegas, NV 89010

\section{U.S. Department of Energy}

Janet Appenzeller-Wing

Environmental Restoration Division

U.S. Department of Energy, Nevada Operations Office

P.O. Box $98518 \mathrm{M} / \mathrm{S} 505$

Las Vegas, NV 89193-8518

Sabine Curtis

Environmental Restoration Division

U.S. Department of Energy, Nevada Operations Office

P.O. Box $98518 \mathrm{M} / \mathrm{S} 505$

Las Vegas, NV 89193-8518

Sabrina Lawrence

Environmental Restoration Division

U.S. Department of Energy, Nevada Operations Office

P.O. Box $98518 \mathrm{M} / \mathrm{S} 505$

Las Vegas, NV 89193-8518

DOE Public Reading Facility

P.O. Box $98521 \mathrm{M} / \mathrm{S}$ NLV040

Las Vegas, NV 89193-8521
2 (Controlled)*

1 (Controlled)*

1 (Uncontrolled)*

1 (Uncontrolled)*
1 (Controlled) 


\section{DISTRIBUTION LIST (Continued)}

DOE/Nevada Operations Office

1 (Uncontrolled)

Technical Information Resource Center

P.O. Box $98521 \mathrm{M} / \mathrm{S} 505$

Las Vegas, NV 89193-8521

U.S. Department of Energy

2 (Uncontrolled)

Office of Scientific and Technical Information

175 Oak Ridge Turnpike

P.O. Box 62

Oak Ridge, TN 37831

\section{Bechtel Nevada}

Correspondence Control

1 (Uncontrolled)*

Bechtel Nevada

P.O. Box $98521 \mathrm{M} / \mathrm{S}$ NLV008

Las Vegas, NV 89193-8521

Environmental Management Correspondence Control

1 (Uncontrolled)*

Bechtel Nevada

P.O. Box $98521 \mathrm{M} / \mathrm{S}$ NLV080

Las Vegas, NV 89193-8521

Jerry Bonn

1 (Uncontrolled)*

Bechtel Nevada

P.O. Box $98521 \mathrm{M} / \mathrm{S}$ NTS306

Las Vegas, NV 89193-8521

Janet Cowley

1 (Uncontrolled)

Bechtel Nevada

P.O. Box $98521 \mathrm{M} / \mathrm{S}$ NTS110

Las Vegas, NV 89193-8521

David Cowser

1 (Uncontrolled)*

Bechtel Nevada

P.O. Box $98521 \mathrm{M} / \mathrm{S}$ NLV082

Las Vegas, NV 89193-8521

Ann Heidema

1 (Uncontrolled)

Bechtel Nevada

P.O. Box 98521 M/S NLV022

Las Vegas, NV 89193-8521 


\section{DISTRIBUTION LIST (Continued)}

Rick Remington

1 (Uncontrolled)

Bechtel Nevada

P.O. Box $98521 \mathrm{M} / \mathrm{S}$ NTS405

Las Vegas, NV 89193-8521

Patrick Matthews

1 (Uncontrolled)

Bechtel Nevada

P.O. Box 98521 M/S NLV180

Las Vegas, NV 89193-852

Kenneth McGlothlin

1 (Uncontrolled)

Bechtel Nevada

P.O. Box $98521 \mathrm{M} / \mathrm{S}$ NTS330

Las Vegas, NV 89193-8521

Steve Nacht

1 (Uncontrolled)*

Bechtel Nevada

P.O. Box 98521 M/S NTS306

Las Vegas, NV 89193-8521

Shannon Parsons-DePry

1 (Uncontrolled)*

Bechtel Nevada

P.O. Box $98521 \mathrm{M} / \mathrm{S}$ NTS306

Las Vegas, NV 89193-8521

Phil Ralphs

1 (Uncontrolled)

Bechtel Nevada

P.O. Box $98521 \mathrm{M} / \mathrm{S}$ NTS330

Las Vegas, NV 89193-8521

\section{IT Corporation}

Kenneth Beach

1 (Uncontrolled)*

IT Corporation

P.O. Box 93838

Las Vegas, NV 89193

Rosa Silver

2 (Controlled)

IT Corporation

P.O. Box 93838

Las Vegas, NV 89193 


\section{DISTRIBUTION LIST (Continued)}

\section{PEER Consultants}

Dean Nelson

1 (Uncontrolled)

PEER Consultants

575 Oak Ridge Turnpike

Oak Ridge, TN 37830

Gary Hudak

1 (Uncontrolled)

PEER Consultants

P.O. Box $98521 \mathrm{M} / \mathrm{S}$ NLV082

Las Vegas, NV 89193-8521 